NBER WORKING PAPER SERIES

U.S. FOREIGN TRADE AND THE

BALANCE OF PAYMENTS, 1800-1913

Robert E. Lipsey

Working Paper No. 4710

\author{
NATIONAL BUREAU OF ECONOMIC RESEARCH \\ 1050 Massachusetts Avenue \\ Cambridge, MA 02138 \\ April 1994
}

This paper was prepared, under the Bureau's program in International Trade and Investment, for eventual publication in the Cambridge Economic History of the United States. I am indebted to Robert Gallman and Stanley Engerman for helpful comments and suggestions on the manuscript, and to Karl Widerquist and Qing Zhang for able research assistance. The opinions expressed are those of the author and do not necessarily represent those of the City University of New York or the National Bureau of Economic Research. This paper is part of NBER's research programs in International Trade and Investment and the Development of the American Economy. 


\section{U.S. FOREIGN TRADE AND THE \\ BALANCE OF PAYMENTS, 1800-1913}

\section{ABSTRACT}

This paper reviews the main developments in U.S. trade and the balance of payments from the first years of the 19th century to the first decade of the 20th.

American export trade was dominated by agricultural and other resource products long after the majority of the labor force had shifted out of agriculture. The shift out of agriculture was more rapid among the major trading partners of the United States because the American land area increased in the first half of the nineteenth century and agricultural land increased throughout the century. The rise in agricultural land area and a rapid decline in transport cost increased the supply of U.S. agricultural products to Europe and further displaced European agriculture and encouraged migration from Europe.

The existence of the large world market, relatively open to the products of American comparative advantage and with a high price elasticity of demand for American exports, encouraged the expansion of U.S. land, agriculture, capital inflows, immigration, and the western migration of population.

Robert E. Lipsey

Queens College and the Graduate Center

C.U.N.Y.

Flushing, NY 11367

and NBER 


\section{U.S. TRADE AROUND 1800}

Trade was on the minds of the entrepreneurs who financed the first settlements in the Americas. They dreamt of riches - the kind that could come only from exploiting the natural resources of areas newly opened to European settlement and exporting the products. They did not envisage financing subsistence farmers or artisans, or manufacturing settlements serving local markets.

As it turned out, the American colonies were, In their early days, heavily involved in exporting. They probably exported something like a quarter of their production in the early years of the 18 th Century (Gallman and Lipsey, in Davis, Easterlin, and Parker, 1972). By the end of the 18th Century that export propensity had been cut in half. Thus, around 1800 , something like ten to fifteen per cent of U.S. output was exported (IbId and Shepherd and Walton 1972, P. 44). To some extent, that decline in the export propensity could be attributed simply to population growth - - larger countries tend to trade less in proportion to their output than smaller countries -. but the decline in exporting was too large for much of it to be attributed to that cause.

Exports of domestic merchandise by the United States at the beginning of the 19 th century were about 3 per cent of world exports and five per cent of Europe's exports at a time when the population of the United States was only about $1 / 2$ of 1 per cent of the world's population and $21 / 2$ per cent of Europe's (U.S. Bureau of the Census, 1975 and Balroch, 1976a, Table 2, P. 18). Thus in terms of exports of its own products per capita, excluding re-exports of products made by others, the United States was twice as trade-oriented as Europe, and more than five times as export-oriented as the world as a whole. 
The United States was also heavily engaged as an intermediary in a variety of indirect "triangular" trades, especially with the nearby European colonies. If we measured the trade propensity by total exports, including re-exports, the U.S. ratios would be about twice as high.

American exports in the early 1800 s were almost all natural resource products. More than three quarters were the output of agriculture in 1803-07 and almost another fifth the output of forests and of the sea. Less than 5 per cent was the product of manufacturing industries (U.S. Congress, 1884 , Table 3). The industry origin of American exports in these years was similar to that of 35 years earlier.

This almost total concentration of exports on natural resource products at the beginning of the 19th Century, and the fact that it almost duplicated the export trade pattern of the mid-18th Century, contrasts with indications that the structure of production had already started to shift away from primary products. If Bairoch's (1982) very rough estimates are to be believed, the United States (or the area that was to become the United States) moved from a level of per capita industrial output far below the world level, and that of even China and India, in 1750, to a level above the average of developed countries and of Europe as a whole around 1800, behind only the UK, by a large margin, and Belgium and Switzerland by narrow margins. Thus, the structure of production seemed to be changing faster than that of other countries without altering the comparative advantage of the United States. Most of the exports from the United States were destined for Europe (over 60 per cent), about a quarter to Great Britain and Ireland. Those shares represented a considerable decline from the period around 1770 (over 70 per cent to Europe, 57 per cent to Great Britain and Northern Ireland alone). 
Almost all the exports not bound for Europe were destined for the West Indies (29 per cent in 1768-72). New England's exports were largely to the West Indies, as were half the exports of the middle colonies, while exports from the southern colonies, the producers of cotton and tobacco, went overwhelmingly to Great Britain. The southern colonies dominated exports to Great Britain in 1768-72 (almost 90 per cent), the middle colonies, exports to Southern Europe (over half), and New England and the middle colonies, exports to the West Indies (three quarters) (U.S. Bureau of the Census, 1975, and Shepherd and Walton, 1972, Pp. 94-95).

The southern colonies were the most dependent on exporting before the American Revolution. Their exports per capita were roughly twice as high as those of New England and the middle colonies. Imports per capita were much more similar among the regions, almost identical between New England and the Middle Colonies on the one hand, and the southern colonies on the other (Shepherd and Walton, p. 113).

A distinctive feature of U.S. trade at the turn of the century was the exceptionally high share of re-exports in total exports. Over half of exports consisted of re-exports, as opposed to exports of U.S. merchandise, in almost every year from 1796 through 1808, until the embargo (U.S. Bureau of the Census, 1975, Sertes 190-192).

This enormous re-exporting activity was a consequence of the European Wars following the early 1790s, in which Great Britain and France each attempted to block the other's trade with its colonies. The effect "... was to throw into our hands the greater part of the colonial carrying trade of the world - an economic prize for which European nations had been fiercely struggling for nearly two centuries" (Callender, Introduction to Chapter VI)." The valuable 
articles of colonial produce, such as sugar, coffee, spirits, cocoa, indigo, pepper, and spices of all kind, were carried by them, either directly to Europe, or brought to the United States, and from thence exported in American vessels. ... The manufactures of Europe, and particularly those of Great Britain, as well as the manufactures and produce of the East Indies and China, were, also, imported, and again exported in large quantities, to the West Indies, South America and elsewhere. (Pitkin, as quoted in Callender, pp. 240241).

The United States not only accounted for a disproportionate share of merchandise trade but also was heavily involved in the export of shipping services. Earnings on ocean freight were about 30 per cent of export earnings during the five years around 1800. The revenue from shipping was larger than from exports of any commodity.

Imports of merchandise almost always exceeded exports at the beginning of the nineteenth century. The negative trade balance was more than offset by large freight earnings, but the U.S. had negative net balances on account of other services, such as insurance and interest. The interest item reflected the accumulated net current account deficit of earlier years, although during the quinquennium around 1800 , there was a small net outflow of capital from the U.S. (North, 1960).

Wilkins (1989) estimated that America's long-term foreign obligations in 1803 were $\$ 65-70$ million or more. These included foreign holdings of federal debt (almost $\$ 5$ million) plus over $\$ 15$ million in holdings of corporate stock, particularly stock in the Bank of the United States (pp. 48 and 646). If Wilkins is correct that North had underestimated the forelgn debt of the United States, the estimates of interest payments and the current account deficit mentioned above are also too low. 
THE GROWTH OF TOTAL U.S. TRADE

\section{The U.S, share of world trade}

As the 19 th century began, U.S. trade was a minor part of world trade. Over the course of the century, that part grew, until in 1900 U.S. exports were 15 per cent of world exports (Table 1). Some of that increase simply reflected the growth of the U.S. population from about a half per cent of that of the world in 1800 to around 5 per cent in 1900 and 1910.

The share of American domestic exports in the total of world export trade was far above the U.S. population share and probably well above the U.S. share in world output throughout the 19th Century. In other words, the U.S. was more export-oriented than the average country. The export

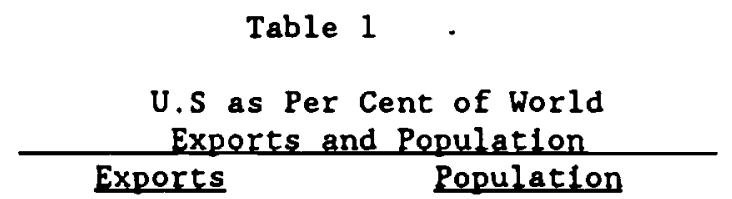

$\begin{array}{lrr}1800 & 3.2 & 0.5 \\ 1860 & 9.8 & 2.5 \\ 1870 & 7.9 & \\ 1880 & 13.2 & 3.6 \\ 1900 & 15.0 & 4.8 \\ 1910 & 12.3 & 5.3 \\ 1913 & 12.9 & \end{array}$

Sources: U.S. Bureau of the Census (1975), Series U191, Bairoch (1976a), p. 18, and Maddison (1962).

share relative to the world rose throughout the 19 th Century and then receded a bit before World War I.

The disparity between the U.S. world export share and its population share was steadily reduced over the 110 years. Relative to Europe, the disparity was much smaller, but $1 t$, too, fell through the 19 th Century, until it disappeared in 1910, with the U.S. at about 20 per cent of Europe's exports 
and population. Thus by that time there was no difference from Europe with respect to the degree of orientation toward exports.

The comparison of U.S. trade with world trade can be made also for total trade measured by the sum of exports and imports (Table 2). Since U.S.

Table 2

U.S. as Per Cent of World Exports and Imports"

$\begin{array}{rr}1800 & 5.3 \\ 1820 & 6.5 \\ 1830 & 5.8 \\ 1840 & 7.2 \\ 1850 & 7.8 \\ 1860 & 9.7 \\ 1870 & 8.2 \\ 1880 & 10.7 \\ 1889 & 9.7\end{array}$

a.S. domestic exports plus imports for consumption (imports passing through customs directly from abroad plus imports passing through customs from bond).

For years when imports for consumption are not avallable, we use general imports minus exports of foreign merchandise (re-exports) as a substitute, assuming no change in inventories in bond.

Source: Rostow (1978), Table B-1, with data in $E$ multiplied by 4.495, and U.S. Bureau of the Census (1975), Series U191 through U194.

imports were not rising as fast as U.S. exports, as the U.S. reduced its foreign borrowing relative to its trade, the combined share levelled off earlier, before the end of the century. At its peak, the U.S. trade share was something around twice the U.S. share of the world's population.

Whatever the measure used, the trend of U.S. trade during the 19th century was one of increasing importance in the world market, particularly for U.S. exports. That growth in importance in trade reflected in large part the 
rising size of the U.S. In terms of population and production, particularly the latter as U.S. growth in output per capita outpaced that of the rest of the world.

\section{Total Trade and Output}

The proportion of U.S. output that was destined for foreign markets went through some wide annual swings before the European peace settlement in 1815 . However, aside from a few years of embargo and war, the main trend in the ratio of exports to aggregate U.S. output in current prices was a decline from the 10.15 per cent of the 1790 s and the much higher levels of the end of the colonial period (Table 3). For the 100 years following the Napoleonic Wars the average decade ratios ranged only from about $51 / 2$ to 7 per cent. The lowest export proportions were around 1830 and in the 1850 s and the highest, after the early period, were in the 20 years after 1890 . The ratios for 1793 to 1860 are lower than those of the colonial period not only because trade declined in importance but also because these national output measures in the denominator include more non-market output - farm improvements and home manufacturing - than earlier and later output measures. By their nature, these forms of output are not likely to be exported. They declined from 15-20 percent to 7 or 8 per cent of conventionally measured output between 1800 and 1860. Thus a conventional output measure would show some continued decline in the trade share in the early 1800 s.

The ratio of exports to GNP in constant dollars tells something of the 
Table 3

U.S. Merchandise Exports and Imports as Percent of GNP

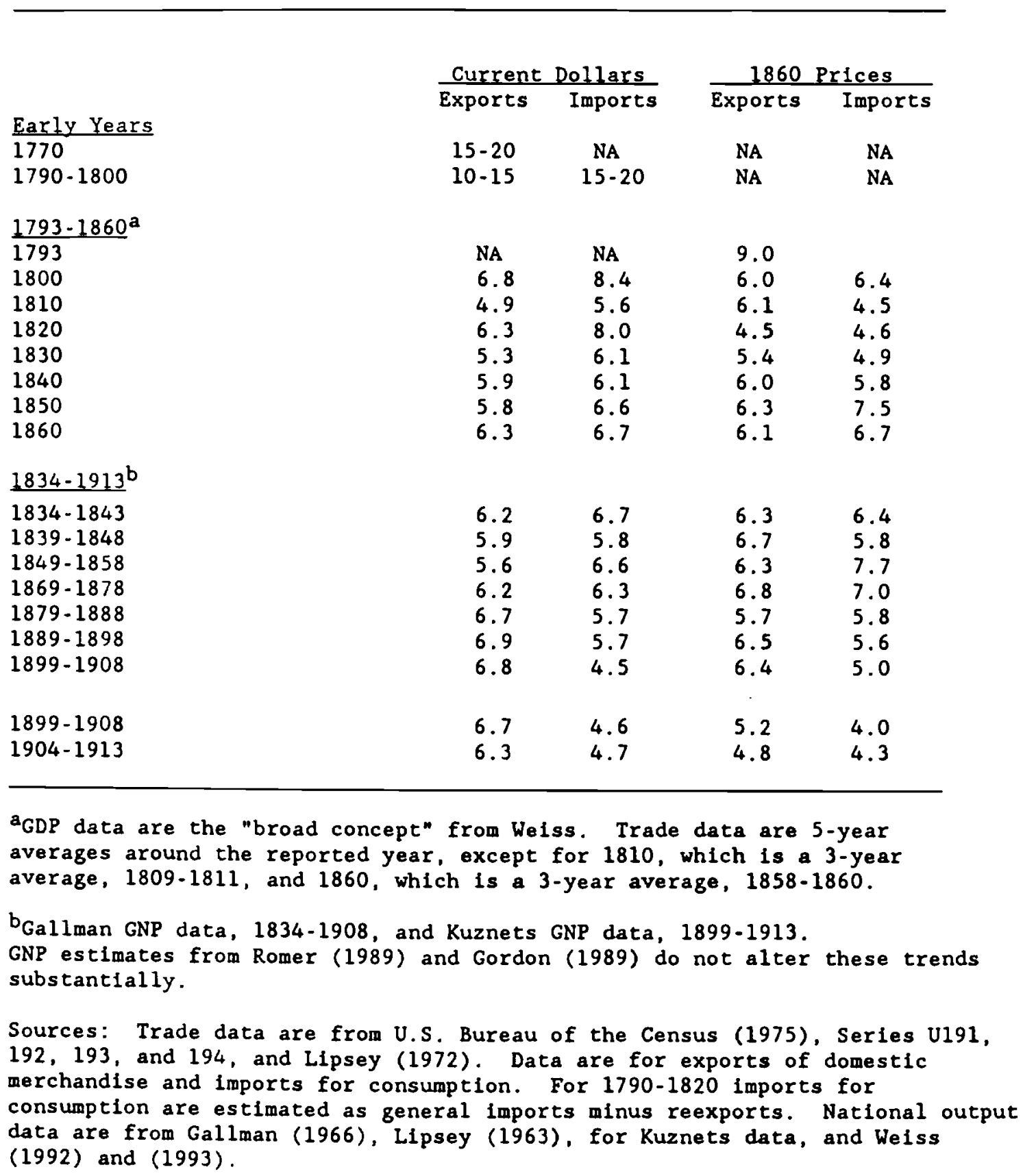


same story of lower dependence on export markets in the 19 th century than earlier. In any case, the greatest dependence on export markets for the U.S. economy as a whole had ended before the 19 th century began, and certainly before the $1820 \mathrm{~s}$.

The U.S. dependence on import trade was even greater than on export trade in the period around 1770, perhaps a third of the colonies' production or consumption. During the first half of the 19 th century the import ratio was above the export ratio, especially in the early years, but imports fell below exports after the 1870 s as the U.S. turned from capital importer to capital exporter.

In real terms, Imports fell even more than exports relative to the GNP, but they followed the same path of decline to 1829-38 and then a recovery. The highest dependence on imports, in real terms, was just before the civil War, after which the ratio fell by about a third. One way to interpret the trade/output ratios is to think of growth in trade that is no faster than growth in output as representing "passive" trade behavior. Growth in trade more rapid than that in output, leading to a rise in the trade/output ratio, can be thought of as "active" or even "aggressive" trade behavior. Most of the period appears to be characterized by passive trade behavior in this sense, but there was a fairly long stretch of years, from the 1850 s through the 1890 s when American exporting became more aggressive, and each decade saw some rise in the export ratio. However, no such trend appears in the constant price series; the trend in the current price ratios reflects a rise in export prices relative to domestic prices in these decades. 
THE U.S. BALANCE OF PAYMENTS AND CAPITAL FLOWS

For most of the period from the inauguration of George Washington to the end of the 19th Century, the United States imported more merchandise than it exported. Only in the last three decades of the century did exports exceed imports, and that export surplus continued into the 20th Century (Table 4).

Table 4

Balance of Merchandise Trade and International Freight, and Interest Payments of the United States

(Annual Averages: millions of dollars)

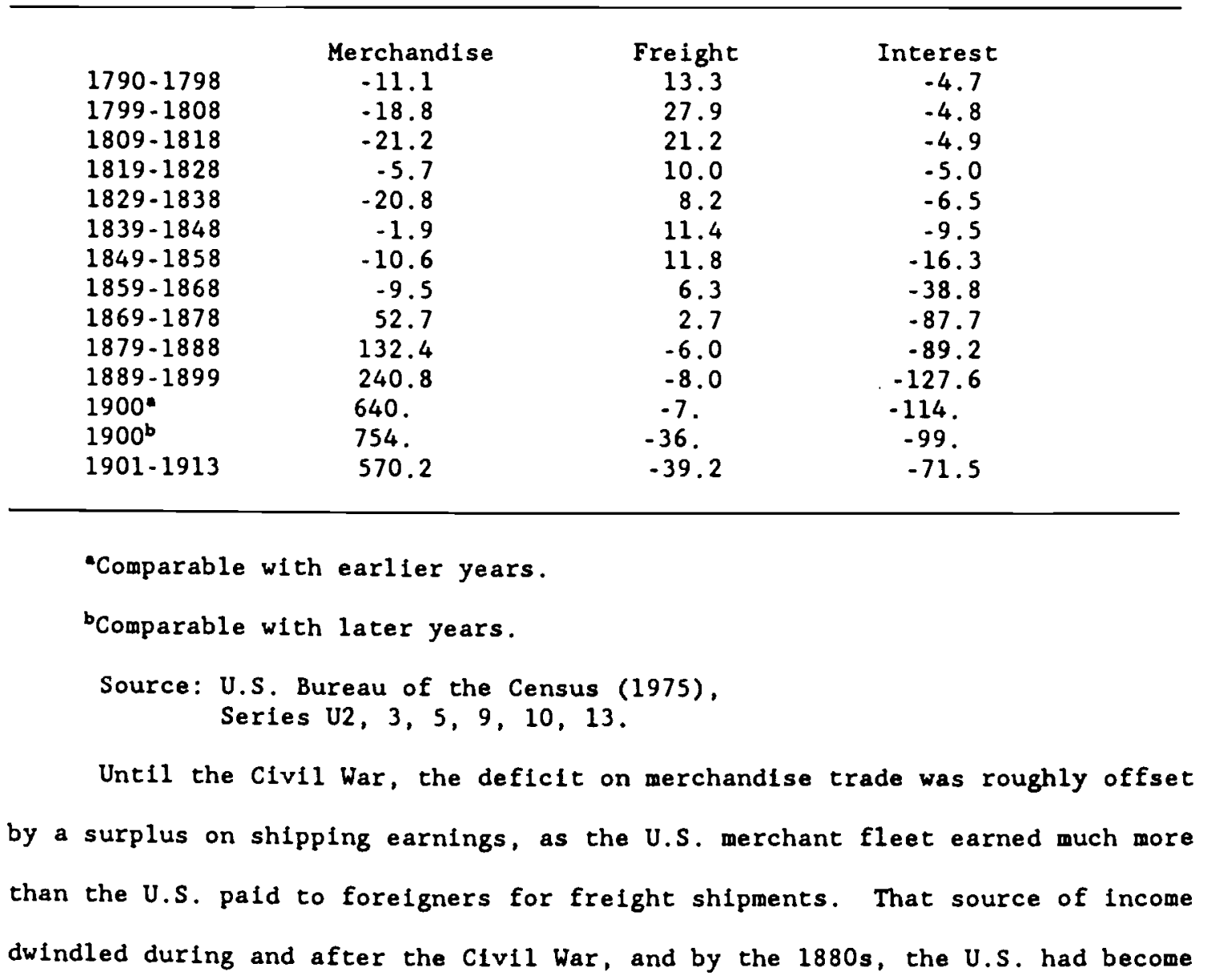


a net importer of shipping services.

Even while freight earnings were offsetting the deficit in the merchandise trade account, the other main current account item, interest, was always in deficit. The United States began its existence as a net debtor and all through the 19 th century and up to World War I it paid out more in interest on its debts than it earned on its foreign assets.

The obverse of this excess of current account payments was the import of capital into the United States. Until an abrupt turn to capital exporting at the end of the century, the United States was a net borrower from foreign countries throughout the 19 th century (Table 5).

The cumulation of borrowing year after year meant that the United states was a net debtor throughout these years. Even at the beginning of World War I. despite fifteen or twenty years in which the United States was a net foreign lender most of the time, the country was still a net debtor to the rest of the world (Table 6).

Table 5

Net Flow of Capital to the United States (annual averages, millions of dollars, current prices)

$1790-1798$

$1799 \cdot 1808$

$1809-1818$

1819.1828

$1829-1838$

$1839-1848$

$1849-1858$

$1859-1868$

$1869-1878$

$1879-1888$

$1889-1899$

$1900^{a}$

$1900^{\mathrm{b}}$

$1901-1913$

$$
\begin{array}{r}
.4 \\
.8 \\
7 \\
1.1 \\
15.8 \\
-2.8 \\
16.7 \\
61.8 \\
73.8 \\
78.4 \\
27.2 \\
-296 \\
-218 \\
5.5
\end{array}
$$

-Comparable with earlier years.

${ }^{b}$ Comparable with later years. 
Table 6

Net Liabilities (-) of the United States, 1789-1914 (Unit: \$ million)

From Cumulation

of Net Capital Flows

From Compilations of Assets \& Liabilities

$\begin{array}{lc}1789 & -60 \\ 1800 & -83 \\ 1803 & -77 \\ 1815 & -80 \\ 1820 & -88^{\mathrm{a}} \\ 1830 & -75 \\ 1840 & -261 \\ 1843 & -217 \mathrm{~b} \\ 1850 & -217^{\mathrm{b}} \\ 1853 & -295 \\ 1860 & -377 \\ 1869 & -1,152 \\ 1870 & -1,252 \\ 1876 & -1,933 \\ 1880 & -1,584 \\ 1890 & -2,894 \\ 1895 & -3,288 \\ 1897 & -3,305 \\ 1900 & -2,501 \\ 1908 & -2,060 \\ 1914 & -2,086\end{array}$

$-225$

$-1,540$

$-2,710$

$-3,875$

$-3,686$

Notes to Table 6

after defaults of $\$ 50$ million in 1816-19

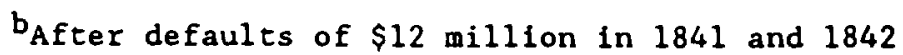

Sources: Lewis (1938), PP. 445 and 560; U.S. Bureau of the Census (1975). Series U40, taken from North (1960) and Simon (1960), extended by cumulating Series U18 to U23. Estimates by Wilkins (1989), Tables 3.1 (pp. 50-52) and 5.4 (pp. 147-150) suggest somewhat larger net liabilities in 1803 , by perhaps $\$ 15$ million, and in 1914 by about $\$ 340$ million. 
These figures on net U.S. liabilities say that forelgners had some net claim on part of the wealth of the United States throughout the 19 th Century. That 1s, foreigners' claims on U.S. wealth were larger than U.S. claims on foreign wealth. One comparison of foreign claims with reproducible wealth suggests that the net foreign claims amounted to almost 14 per cent of wealth at the beginning of the century. That share fell to about 7 per cent by 1850 , 4 per cent by 1900, and only two per cent on the eve of World War I (Davis, 1972. Table 8.12). More recent calculations by Gallman (1992) that raise the estimated value of reproducible wealth, but put a rather low figure on foreign claims in comparison to Lewis (1938) and Wilkins (1989), are summarized in Table 7. They describe a fall in the foreign claims from 13 per cent of domestic capital, excluding land, in 1774 to 9 per cent at the end of the 18 th century, and then some sharp fluctuations through the 19 th century. These reflect not only inflows and outflows of capital and the rate of U.S. capital formation, but also the effects of U.S. inflation, which tended at times to reduce the ratio by raising the nominal value of U.S. capltal.

There are several ways to view the role of these flows of financial capital in American development. One is as a source of financing for aggregate capital formation, permitting faster accumulation of capital than would have taken place if only domestic financing had been avallable. On this basis, it is hard to suppose that imports of capital had a great influence on the rate of development during most of the nineteenth century. The capital inflows or changes in net foreign obligations were rarely more than 6 percent of gross capital formation or of changes in the domestic capital stock of the United States (Table 8). The major exceptions were 1815 to 1840 and the period including the Civil War, 1860 to 1870, when the main foreign investment 
Table 7

Net Foreign Claims as Per Cent of Value of Domestic Capital in Current and 1860 Prices, 1774-1900

\begin{tabular}{lcc}
\hline & $\begin{array}{l}\text { Current } \\
\text { Prices }\end{array}$ & $\begin{array}{c}1860 \\
\text { Prices }\end{array}$ \\
1774 & 12.9 & 12.8 \\
1799 & 9.2 & 9.1 \\
1805 & 5.7 & 5.7 \\
1815 & 3.1 & 3.0 \\
1840 & 6.2 & 6.3 \\
1850 & 1.3 & 1.3 \\
1860 & 1.2 & 1.2 \\
1870 & 6.9 & 6.9 \\
1880 & 5.3 & 5.3 \\
1890 & 4.8 & 4.8 \\
1900 & 1.6 & 1.6 \\
\hline
\end{tabular}

Source: Gallman (1992), Tables 2.1, 2.2, and 2.4. 
Tabl* 8

Changes in International Clasme on the United states and Net Inflows of Capital as Per Cent of Changes In Domestic Capital Stock and Grose Dowestlc Capltal Formation

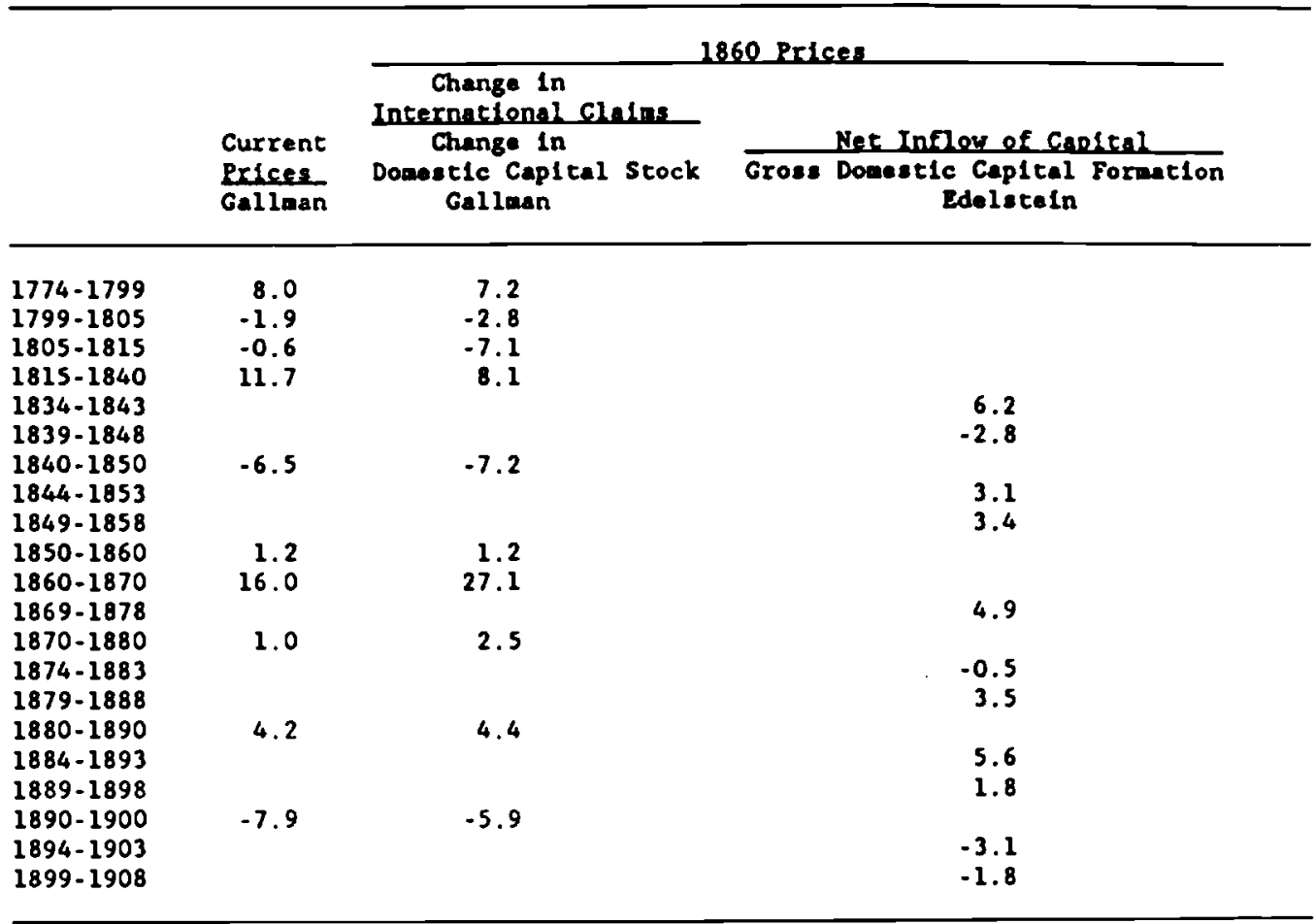

Sources: Galloan (1992), Tables 2.1, 2.2, and 2.4 Edelsteln (1982). Table 10.1 cols. 1 and 3 . 
was in federal government bonds. Edelstein has suggested that U.S. borrowing from foreign countries rose when U.S. capital formation surged; borrowing tapered off as U.S. saving, rising more gradually and steadily, caught up with capital formation. Thus, investment from abroad accommodated the large spurts in the demand for capital that characterized the rapidly growing economy.

There may have been other roles for borrowing from abroad. One might have been to supply funds for particularly risky forms of capital formation at a lower interest rate than would have been required by domestic lenders. Another might have been to supply funds when, in the face of heavy demands by rapidly growing sectors, U.S. domestic lenders' needs for diversification of risks made them reluctant to offer sufficient financing to these sectors. Another interpretation is that U.S. railway and government securities, relatively safe and requiring less local knowledge than investment in smallerscale enterprises in agriculture, mining, and manufacturing, tended to be sold overseas, while domestic suppliers of capital invested in the riskier, but more profitable, sectors (Edelstein 1982, 237-38).

The bulk of foreign Investment in the United States was portfolio investment rather than direct investment. That is, it consisted of purchases of bonds or, to a small extent, equities, that did not involve control over the enterprise receiving the capital. Just before World War I, about 80 percent of the stock of long-term foreign investment in the United States was portfolio investment; the same had been true for the flow over a long period (Edelstein 1982, 36 and 37). Governments and railways were the chief borrowers, and most of the financing was in the form of bonds rather than equities.

In 1789, it was public debt that was the main channel for foreign 
capital, and Wilkins (1989, Table 2.1, p. 32), estimates that almost 30 per cent was held abroad, mainly in France and Holland. That was clearly infrastructure financing, since it supported the establishment of the United States as an independent country. In 1803, foreigners also held a third of corporate stock, mainly of banks (Wilkins, 1989, Table 2.3, p. 37). The Louisiana Purchase in 1803 added about $\$ 11$ million to the total federal debt and the same amount to the federal debt held by foreigners, so that we can particularly describe this important jump in the size of the U.S. economy as having been financed from abroad.

Throughout the first half of the 19 th Century, almost all foreign financing went to governments, first the federal government and later, state governments, and to banks (Wilkins, 1989. Table 3.1, pp. 50-51). Only after that did railroads become a major field for foreign capital, but federal borrowing during the Civil War far exceeded the total of other borrowing through the $1870 \mathrm{~s}$. We know more about British capital than about that of other countries, but that is not a great handicap because the British role was so large, over three-quarters of long-term foreign investment in the U.S. at the end of the 19th century and still 60 percent in 1914 (Wilkins, 1989, Table 58, p. 159).

Most of the foreign investment, whether for government or private companies, went to large, lumpy, social overhead capital projects, such as canals, railways, electrical utilities, and telephone and telegraph systems (Edelstein 1982, 39-41). Manufacturing enterprises were probably almost all too small to seek foreign financing by floating stock or bond issues, or in most cases, by any type of public financing, even from domestic sources. There were many instances of manufacturing enterprises set up by foreign 
craftsmen or entrepreneurs with special knowledge or skills. However, in an era in which transportation and communication were slow by modern standards, these often involved the migration of the owners and eventual conversion of their enterprises into domestic entities. Thus, these enterprises involved mainly a flow of human capital to the United States.

After 1865, relatively little of the flow of new foreign financing went into government securities. From 1865 through 1914 , over 60 per cent of British portfolio investment flowed into transportation, almost entirely railroads. Manufacturing, utilities, mining, and finance and real estate each accounted for 6 to 7 per cent, as did all levels of government (Wilkins, 1989, Table 5-9, p. 164). In 1910, 85 per cent of British investment was in railroads, according to one estimate.

The likelihood that foreign investment was much more important in the flow of capital to the railroad sector than in U.S. fixed investment as a whole is suggested by the fact that the value of foreign investment in U.S. railroads in 1914 was about a quarter of the book value of railroad road and equipment (Wilkins, 1989, Table 6.1, p. 194, and HS, Series Q356). British Investment alone was 16 per cent of the book value in 1914 (Idem). Foreign holdings were estimated by Jenks to range from 20 per cent to a third of the nominal value of U.S. rallroad securities between 1873 and 1914 (Wilkins, 1989, Table 6.4, p. 198).

Since the United States was inferior to European countries in technology in a number of Industries during the 19th century, it may seem surprising that there was so little inflow of direct investment, a natural channel for the exploitation of technological advantages. Transportation and communication were so slow, by modern standards, that it was almost impossible to control a 
subsidiary enterprise from across an ocean. Under those circumstances, the transfer of technology and skills took somewhat different forms, particularly the migration of key personnel, often children or other relatives, to establish subsidiary enterprises or to manage them once they were acquired. The enterprises were frequently what Mira Wilkins (1989) referred to as "freestanding" enterprises, in the sense that while they were owned by foreigners, they were not subsidiaries of foreign companies. Such enterprises were likely over time to evolve into independent, domestic U.S. firms through the migration of their owners to the United States and their adaptation to American circumstances. In the end, the flow of financial capital was intertwined with a flow of human capital.

Immigration is often thought of as a movement of labor, but it is also a flow of human capital. Movements of human capital are not traditionally included in balance of payments accounts, since no monetary payment is Involved, at least when there is no slavery. However, the flow of human capital may have been more important to U.S. development than the flows of financial capital. In terms of numbers, immigration into the United states in each decade from the 1830 s through the beginning of World War I ranged from about 5 percent to 10 percent of the number already in the country (U.S. Bureau of the Census 1975, Series A 6, and C 89). Furthermore, most of the immigrants (a 50 percent larger proportion than in the population as a whole) were between fifteen and forty-four years of age (U.S. Bureau of the Census 1975, Series C 119, C 122-27, C 138, and C 141). They came to the United States with most of their rearing costs already incurred in their home countries and with a large part of their working lives still ahead of them. Some notion of the relative importance of the human and financial 
capital flows is provided by Neal and Uselding (1972), who estimated the "resource pool arising from net immigration." The two types of inward capital flows are compared in Table 9.

Table 9

\author{
Cumulated Net Capital Inflow and Resources from Net Immigration \\ (Unit: millions of $\$ 1860$ ) \\ Net Capital Inflow \\ $1799-1860$ \\ $1860-1890$ \\ 56 \\ 1,660 \\ Immigration \\ $198.5-934.9$ \\ $3,514.2-6,609.0$ \\ Source: Gallman (1992) and Neal and Uselding (1972), Table V.
}

Even at the peak period of financial capital inflow, 1860-1890 (the United States became a net exporter of capital after that), the low end of the range for the estimate of the value of the human capital inflow embodied in immigration was more than twice the financial capital flow. Before the Civil War, the relative importance of the human capital flow was even greater, and in the 1900-1909 decade, when the net financial capital flow was outward rather than inward, the inflow of resources through immigration continued at a high level. Thus the contribution of the inflow of resources from abroad to American growth was much greater than might be inferred from the conventional capital inflow data. 
CHANGES IN THE COMPOSITION OF U.S. TRADE

AND THE COMPaRative adVANTAGE OF THE U.S.

\section{The Composition of Trade}

The composition of American exports in the late 18th century and the beginning of the 19 th century reflected the fact that American comparative advantage was based on the exploitation of abundant natural resources. The largest part of exports consisted of agricultural products, but products of the forest and of the sea were also important: 19 per cent of the total in 1803-1810, already a large decline from the 28 per cent of British continental colonies in 1770 (U.S. Bureau of the Census, 1975, Series 2294). Thus, the first great shift in export composition, as population moved away from the coast and as forest land was cleared for farming, was, within resource products, away from forest and ocean products toward those from agriculture. In the decades before the Civil War around 80 per cent of U.S. exports were of agricultural products.

An indication of the shifts in importance of the sectors from which exports originated is given by Table 10. One of the trends is the shift away from forestry and fishing, responsible for almost 20 per cent of exports in the first decade, already down from 27 per cent in 1770 , but for less than 7 per cent before the Civil War.

There was some rise in the importance of manufacturing as a source of U.S. exports before the Civil War, but American exports were dominated throughout the period by agriculture. A more surprising fact is that despite the rise of manufacturing industry in the United States, discussed below, agricultural products were over 70 per cent of total U.S. exports throughout the 19th century and a majority of exports up to World War I. 
Table 10

Composition of U.S. Exports, by Broad Commodity Categories, 1770 and 1803-1913

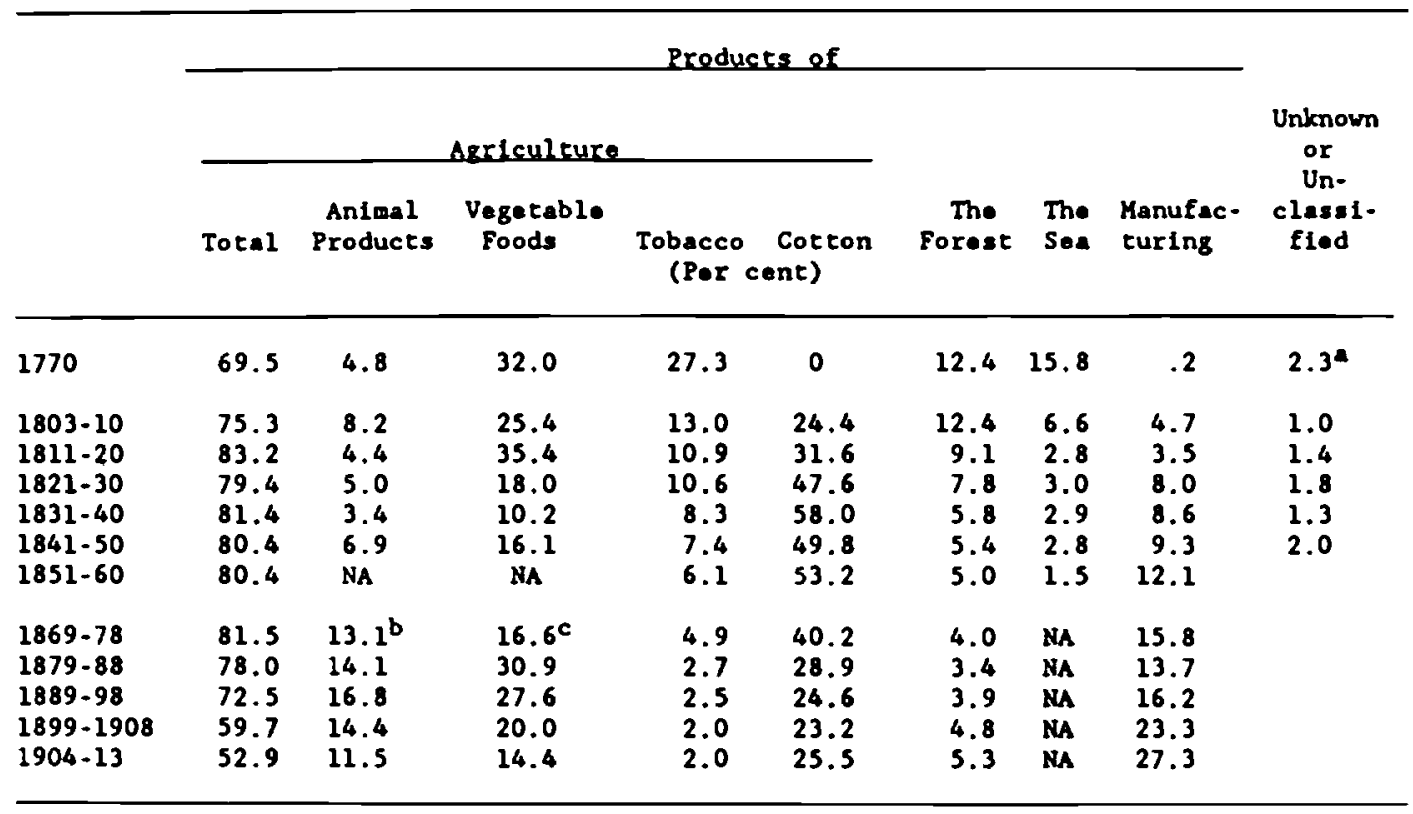

Mainly products of mines

beats and neat products only. The corresponding figure for 1879.88 is 10.0 per cent.

Wheat and wheat flour only. The corresponding figure for 1879.1888 is 20.4 percent

Sources: 1770: U.S. Bureau of the Census (1975), Series 2294 . Data refer to British Continontal Colonies.

1803-1850: U.S. Congress, House of Ropresentetives (1884), Table 2 .

1851-1860: U.S. Treasury Department (1860), Table 25, p. 401.

1869-1913: L1psey (1963), Tables A-6, A-7, B-5, and C-5. Meats are Intermedlate Class 106: animal products, 107 plus 114; vegetable foods, 104 plus 113 minus 107 . Tobacco is minor class 025 . U.S. Bureau of the Census (1975), Vol. II, Series U 274-294. Meats and weat products are series $U$ 285; wheat and wheat flour is serfes $U 281$, products of the forest are series $U 286$, $U 288$, and $U 289$. 
Within agriculture, the first half of the century saw the decline of tobacco, the great colonial staple, and its replacement by cotton, which alone accounted for half or more of exports from the 1830 s to the beginning of the Civil War. Cotton remained important for the rest of the century, and in the years up to World War I, was still around a quarter of the value of all exports.

A different view of changes in the composition of trade is provided by broad economic classes of goods. Before the Civil War, the United States was mainly an exporter of raw materials and foods. Raw materials alone were 60 per cent or more of exports, food exports were about 20-25 per cent, and semimanufactures and finished manufactures accounted for the rest, with the finished goods rising in importance and the semi-manufactures declining (Table 11).

The period after the Civil War saw very different trends. The share of raw materials fell to around 30 per cent and food exports increased to replace them, reaching a peak importance of over $40-45$ per cent in the last two decades of the 19 th century and then declining to about a quarter just before World War I. Thus raw materials and foods together remained overwhelmingly predominant in exports almost until the eve of World War I, at 80 per cent or close to it through the $1880 \mathrm{~s}$, and three quarters of the total through 1908. The changing comparative advantage of the United States can be described by a comparison of the role of resource products in exports as compared with imports. By Vanek's (1963) definition of resource products (crude materials and crude foods) the share of these products in exports fell from four times that in imports to less than that in imports between 1820 and 1904-13, with the sharpest drop coming between the beginning and end of the Civil War. By a 
Table 11

Composition of U.S. Exports and Imports by Econonic Classes

EXPORTS

\begin{tabular}{|c|c|c|c|c|c|c|}
\hline \multirow[b]{2}{*}{ YEAR } & \multirow[b]{2}{*}{ TOTAL } & \multirow[b]{2}{*}{$\begin{array}{c}\text { CRUDE } \\
\text { MATERIALS }\end{array}$} & \multicolumn{2}{|c|}{ FOODS } & \multirow[b]{2}{*}{$\begin{array}{l}\text { SEAII- } \\
\text { MANUFACTURES }\end{array}$} & \multirow[b]{2}{*}{$\begin{array}{l}\text { FINISHED } \\
\text { MANUFACTURES }\end{array}$} \\
\hline & & & CRUDE & MANUFACTURED & & \\
\hline 1820 & 100.0 & 59.6 & 3.8 & 19.2 & 9.6 & 5.8 \\
\hline 1830 & 100.0 & 62.7 & 5.1 & 16.9 & 6.8 & 8.5 \\
\hline 1840 & 100.0 & 67.9 & 4.5 & 14.3 & 4.5 & 9.8 \\
\hline 1850 & 100.0 & 62.2 & 5.9 & 14.8 & 4.4 & 12.6 \\
\hline $1850-1858$ & 100.0 & 60.3 & 7.0 & 16.1 & 4.1 & 12.6 \\
\hline $1859-1868$ & 100.0 & 41.3 & 14.0 & 23.8 & 5.3 & 15.7 \\
\hline $1869 \cdot 1878$ & 100.0 & 44.1 & 15.2 & 20.0 & 4.7 & 15.9 \\
\hline $1879-1888$ & 100.0 & 34.2 & 20.9 & 25.0 & 4.8 & 15.1 \\
\hline 1889.1898 & 100.0 & 32.9 & 17.1 & 25.9 & 7.0 & 17.1 \\
\hline $1899-1908$ & 100.0 & 29.2 & 12.7 & 21.7 & 11.9 & 24.6 \\
\hline $1904 \cdot 1913$ & 100.0 & 32.3 & 7.7 & 16.8 & 14.8 & 28.3 \\
\hline \multicolumn{7}{|c|}{ IMPORTS } \\
\hline & & & \multicolumn{2}{|c|}{ FOODS } & & \\
\hline YEAR & TOTAL & $\begin{array}{c}\text { CRUDE } \\
\text { MATERIALS }\end{array}$ & CRUDE & MANUFACTURED & $\begin{array}{l}\text { SEMI- } \\
\text { MANUFACTURES }\end{array}$ & $\begin{array}{l}\text { FINISHED } \\
\text { MANUFACTURES }\end{array}$ \\
\hline 1821 & 100.0 & 5.5 & 10.9 & 20.0 & 7.3 & 56.4 \\
\hline 1830 & 100.0 & 7.9 & 11.1 & 15.9 & 7.9 & 57.1 \\
\hline 1840 & 100.0 & 12.2 & 15.3 & 15.3 & 11.2 & 44.9 \\
\hline 1850 & 100.0 & 7.5 & 10.3 & 12.1 & 14.9 & 54.6 \\
\hline $1850-1858$ & 100.0 & 8.7 & 11.2 & 14.4 & 13.2 & 52.5 \\
\hline $1859-1868$ & 100.0 & 13.0 & 13.9 & 17.7 & 13.1 & 42.3 \\
\hline $1869-1878$ & 100.0 & 15.7 & 15.5 & 21.4 & 12.8 & 34.6 \\
\hline $1879-1888$ & 100.0 & 20.6 & 15.4 & 18.5 & 14.5 & 30.9 \\
\hline $1889 \cdot 1898$ & 100.0 & 24.7 & 17.7 & 17.0 & 13.9 & 26.7 \\
\hline $1899-1908$ & 100.0 & 33.0 & 12.4 & 13.0 & 16.6 & 25.0 \\
\hline $1904-1913$ & 100.0 & 34.6 & 11.9 & 11.8 & 17.7 & 24.1 \\
\hline
\end{tabular}

Source: U.S. Bureau of the Census (1975), Vol.II, Pp. 889-890. 
broader definition of resource products that includes manufactured foods such as flour and meat, the decline in the resource share was only about half as large and the Civil War played less of a role. Since the value added in manufacturing is relatively small in these industries the broader definition seems more appropriate. Nevertheless, the shift away from U.S. comparative advantage in resource products is very substantial, from an export share over twice the share in imports to virtual equality.

All this is not to say that manufactured goods other than foods played no role in exports. The share of finished manufactures started very low: a little over 5 per cent in 1820 and still less than 10 per cent in 1840, but reached over a quarter in the first two periods of the twentieth century, over 40 per cent for finished manufactures and semimanufactures together. Their steady growth in importance was interrupted in the period from the Civil War through the 1880 s as crude food exports pushed them aside for a time. As a result, the share of finished manufactures in U.S. exports in the 1880 s and 1890 s ( 15 and 17 per cent) was not very high compared to that of "third world" countries around 1900, about 11 per cent according to Bairoch and Etemad (1985, Table 2.1), if we remove nonferrous metals from their manufactured category for comparability.

On the import side, the United States began its existence as an Importer of finished manufactures, more than half the total at first. As these products grew in importance among exports, they declined among imports. By the beginning of the 20 th century the United States was no longer a net importer of finished manufactures from the rest of the world. The manufactures share in exports grew from a tenth of that in imports in 1820-21 to more than the share in imports by 1904-13. 
The Industry Distribution of Trade Relative to Output and Employment

The share of agriculture in American exports throughout the 19 th century did not reflect the transformation that was taking place more generally in the American economy. In the economy as a whole, agriculture was shrinking in importance throughout the 19th century. The share of agricultural output in conventionally defined GDP fell from almost half in 1800 to a third in 1860 (Weiss, 1993). If farm improvement is included in agricultural output and it and home manufacturing are included in GDP the decline appears more gradual and concentrated in the period from 1840 to 1860 . The general story of the period, strongly influenced by the assumptions made in calculating GDP, is that agriculture was already much more dependent on exports than other sectors of the U.S. economy and that this dependence, as measured by the ratio of exports to output, increased substantially up to the beginning of the Civil War.

After the Civil War, farm gross product in current prices fell from forty per cent or so of GNP in 1869 to twenty per cent in. 1900 and only a little over fifteen per cent in 1913, when the agricultural share in American exports was still over half.

Estimates of the industrial distribution of the U.S. labor force also show the shift out of agriculture, particularly after 1810 or 1820 . The contrast between the stability of agriculture's share in exports and the decline in agriculture's share of the labor force is not quite as strong in Weiss' (1992) estimates - the agricultural share fell from 74 per cent in 1800 to 56 per cent in 1860 - as in those of Lebergott (1966) and David (1967) - 83 per cent to 53 per cent over the same period. All tell a similar story, however, of a large rise in the ratio of exports per worker in agriculture 
relative to other sectors. Agriculture's share of the labor force continued to fall in the second half of the century, from a little over half at the beginning of the Civil War, to forty per cent in 1900 and a little over thirty per cent by 1910, according to Lebergott (1966). Rapid as the decline in the agricultural share of the U.S. labor force was from before the Civil War to the beginning of World War I, the fall was even steeper in some other countries. For example, in Great Britain, the largest market by far for U.S. exports, the share of the labor force in agriculture, forestry, and fishing fell by more than half between 1861 and 1911 (Mitchell, 1978, p. 61), and the share of agriculture alone fell by 60 per cent from 1841 to 1901 , after a decline of a third in the previous forty years (Kuznets, 1966, Table 3.2).

The combination of the falling importance of agriculture in production and the labor force with its stubbornly high share in exports meant that American agriculture was becoming increasingly dependent on exporting. Agricultural exports were about a tenth of agricultural gross income in the early $1800 s$, reached more than a fifth and at times almost a quarter in the late 19 th century, and were still close to a fifth through the beginning of World War I (Table 12).

Thus the export dependence (exports/output) of the agricultural sector, always high relative to that of the country as a whole, went from being twice as high in the early 19 th century to three and a half times as high during the late nineteenth and early twentieth centuries.

The United States retained much of its comparative advantage in agricultural products far into the period of industrialization and far into the era when the United States was becoming a major industrial power. One reason for this was that, in contrast to European countries, the United States 
Table 12

Export Dependence (Exports/Output) of the U.S. and U.S. Agriculture

$\begin{array}{lccc} & \text { Agriculture } & \begin{array}{c}\text { U.S. } \\ \text { Total }\end{array} & \begin{array}{r}\text { Agricultural Rel } \\ \text { Total }\end{array} \\ 1810 & 9.8 & 4.9 & 2.0 \\ 1820 & 14.2 & 6.3 & 2.3 \\ 1830 & 10.6 & 5.3 & 2.0 \\ 1840 & 12.3 & 5.9 & 2.1 \\ 1850 & 14.7 & 5.8 & 2.5 \\ 1860 & 15.3 & 6.3 & 2.4 \\ 1869-78 & 18 & 6.2 & 2.9 \\ 1879-88 & 21 & 6.7 & 3.1 \\ 1889-98 & 24 & 6.9 & 3.5 \\ 1899-1908 & 22 & 6.7 & 3.3 \\ 1904-13 & 19 & 6.3 & 3.0\end{array}$

Source: 1810-1860: Table 3 and sources cited in Tables 3 and 10.

1869-1913: Lipsey, 1972, Tables 14.1 and 14.2. All these ratios are overstated because the denominators are gross product originating, net of purchases of inputs from other industries, but the numerators are export values with no deductions for purchased inputs. 
was increasing its land area even as its population, labor force, and capital stock were growing. Between 1790 and 1850, the end of the period of growth in area, the land area of the United States more than tripled. The population grew more than twice as fast, but the enormous increase in acreage kept the land/population ratio to less than a doubling. Over some periods, such as 1800 to 1810 or 1820 , or 1840 to 1850 , the ratio declined (U.S. Bureau of the Census, 1975, Series A-1 to A-5). From 1800 to 1850 the population/land ratio in the U.S. rose less than that of Europe and Asiatic Russia, despite the far more rapid population growth rate in the United States.

Despite the declining importance of agriculture, the second half of the nineteenth century represented a climax in the development of American agriculture and the agricultural export trade. Farm productivity and output per capita grew more rapidly in the second half of the century than in the first half and the per capita output of agricultural products reached levels never again attained in later years.

This rapid growth of farm output involved large expansions in the farming area of the United States, even after the land area of the United States itself stopped growing; the land added to farms in the 50 years after 1850 was almost twice the 1850 average. Many of the great increases in farm production were associated with the migration of production to new areas. In the first half of the century, cotton production migrated from Georgia and South Carolina to Mississippi, Louisiana, Texas, and Arkansas. After 1850 the main shift was the migration of grain and meat production from the Atlantic states and the Ohio Valley to the states west of the Mississippi.

These additions to farm acreage involved increases in the U.S. supply of agricultural products. At the same time, the supply of North American 
agricultural products, as seen from Europe, was increased further by a rapid decline in freight rates both within the United States and on shipments across the Atlantic.

Rapidly increasing U.S. production and falling prices, combined with the decline of transport costs, enabled American products to drive continental suppliers out of the British market for grains and meat during the years after the Civil War. Eventually the same transport-cost developments, as well as increases in U.S. domestic demand and the development of still newer producing areas such as Canada, Australia, and Argentina brought about the dethronement of the United States as the major supplier of agricultural products to Europe.

One of the countries that felt the impact of U.S. grain exports was Sweden. As Swedish grain exports declined in the face of American competition, many swedish farmers gave up their less productive Swedish land resources and moved to the United States, especially to Minnesota and Illinois. There they combined their human capital acquired in Sweden, their farming skills, with the more productive American land and climate, and thus added to the U.S. grain supply still further (Blomström, Lipsey, and ohlsson).

The significance of the foreign market was greatest during periods of rapid expansions in agricultural output. For example, although post-Civil War agricultural exports ranged between 20 and 25 percent of output, the increase in agricultural exports was about one third of the increase in output from 1870-1874 to the peak in 1895-1899. Exports absorbed large proportions of increases in agricultural output when agricultural output was growing most rapidly. They sustained agricultural prices, which might otherwise have dropped sharply, given the relatively low domestic elasticity of demand for most agricultural products. In that way, exports encouraged the flow of 
resources (both land and settlers) into new agricultural production. The flow might otherwise have been cut off at an earlier point if large price doclines had made new settlement unatractive.

The histories of individual commodities contain illustrations of two somewhat different roles for export markets. One is to supply the initial impetus for the settlement of new lands and for production of a commodity. The other is to provide a wider market and a higher demand elasticity, and in some cases a more efficient scale of production, for goods that are initially made for local, or domestic, markets. Several products fall into the first of the categories mentioned -. those initially oriented toward the export market and always mainly dependent on it. Tobacco, for example, was produced largely for export from an early stage in its development. Over two thirds of the crop was exported in 1800 and about three quarters in 1810. Cotton was the epitome of an export crop. 80 percent of the output was exported in the $1830 \mathrm{~s}$, when it first reached major Importance. Even in the second half of the nineteenth century, when cotton and tobacco had long since declined in significance as parts of American agriculture, the proportion of the crops exported remained over 50 percent.

Important as cotton and tobacco were, they accounted for only about a sixth of agricultural output in 1860 , and were responsible for less than a fifth of the growth of agricultural exports between 1860 and 1890 , although they had provided more than 80 percent of the growth in U.S. agricultural exports between 1800 and 1860 . Many of the other agricultural products -. even those that were export items .. fell into the second class described above. They began as essentially domestic products but became export goods as American production developed and became more efficient and as transportation 
costs fell. The export market was not the main impetus in the early stages of development. The course of the trade/output ratios of some of these other products, such as grains, was very different from those of cotton and tobacco. At no time did the grain export ratio reach 50 percent -- domestic consumption was always the main destination of grain output. However, the export market did, at times, take a large fraction of increases in the output of grains; in the case of wheat, for example, almost 50 percent of the increase in output from 1869-1873 to 1894-1898 went into exports.

For some products, the export/output ratios are deceptive, because the output is sold to another domestic industry and processed before exporting. Exports of live animals were almost always a small fraction of farm output, but the export of meat products accounted for considerable proportions of the farm sales. In the case of pork products, for example, the rise in exports was at times over 50 percent of the addition to farm income from hogs, although exports never accounted for a high proportion of any year's output. Exports of the animals themselves were negligible.

Thus the situation for grains and meat products differed from that of cotton and tobacco, to judge from the lower export/output ratios and the wider fluctuations in these ratios. There was, probably, a steady increase in domestic demand with the growth of population and urbanization. Domestic demand was, however, inelastic. That is, a decline in price would not have produced a great increase in domestic food consumption; an increase in output, all thrown on the domestic market, would have caused severe price declines. Foreign demand, at least in markets in which there were other suppliers to replace, was much more elastic. The United States could increase its sales abroad by replacing other foreign suppliers and the American 
agricultural sector did not have to rely on raising the domestic consumption of foods by lowering prices.

Changes in supply were irregular, as in the case of cotton, and also involved large population movements to new farming areas. These population movements were, however, partly autonomous - that is, they were not simply a response to rising prices. If there had been no forelgn market, but only the domestic market with its inelastic demand, a period of rising supply from new land settlement, if it would have taken place, would have brought severe price declines. Thus, the existence of the foreign markets and their openness to U.S. exports may have been an essential pre-condition for rapid agricultural expansion.

Aside from agriculture, primary industries that were important in exports at the beginning of the nineteenth century, and even more in the eighteenth century, were forestry and fisheries. Both were declining as export industries during the first half of the nineteenth century, and the fisheries had already declined considerably in the final years of the eighteenth. Products of the sea fell from 16 percent of exports in 1770 to 7 percent in 1803-1810 and 2 percent in 1851-1860; and forest products, which accounted for 12 percent of the value of exports in 1770 and 1803-1810, declined to 5 percent in 1851-1860.

The export/output ratio for forestry was probably above 15 percent in the early 1800s. In the case of fishing, exports in the 10 or 15 years before the Civil War appeared to be well over a quarter of the total value of output, and the ratio must have been higher in earlier years. It might well have been a third or more, especially for the whale fisheries, in the 1770s. The importance of export markets thus seems to have been great in a wide range of 
primary products, including those derived from forestry and fishing as well as farming.

Even in 1869, before the peak in farm exports, the export ratio for agriculture was more than twice as great as the ratio for manufacturing. The few manufactured products that were exported reflected the richness of American resources, rather than American capabilities in processing them. The export ratio was inflated by the figure for food products, mainly grain and meat products, in which a high fraction of the value entering the final cost, over 80 percent, had been added in agriculture rather than in manufacturing.

The petroleum and coal products group, also highly dependent on a resource base, was the only manufacturing industry in which exports played a large role in the early stages of development. Exports accounted for more than half of output in 1869 and 1879, and the share remained above one quarter through 1914. In no other manufacturing industry, even those such as foods which were close to the primary production stage, did the ratios ever go above 15 percent. In 1869, 14 out of 18 manufacturing industries showed export ratios below 4 percent, and 10 out of 18 ratios were below 2 percent.

The dominance of export trade as a factor in U.S. growth was confined to agriculture and other primary industries. Within agriculture, exports played a major role in two different ways. In some products, particularly in the early decades, the foreign market was the main outlet and the main stimulus to the flow of resources and the growth of production. In others, especially in the second half of the nineteenth century, the foreign market eased the path of rapid growth in output by cushioning the effect of increased supply on price, an effect which we might expect to have been large in view of the presumably low price elasticities of domestic demand for agricultural 
products.

Another indicator of the trend in American comparative advantage is provided by sectoral export/output ratios, available only from 1869 on. While the trends are not very strong, they do differ in direction. The export ratio in agriculture reached a peak in 1879 and then mainly declined (Table 13). The ratio in resource-oriented manufacturing also reached its peak in 1879, while for other manufactured goods, the export ratio showed an upward trend, if any.

Table 13

Export/Output Ratios (Per Cent)

For Agriculture and Manufacturing

$\begin{array}{lcccccc} & 1869 & 1879 & 1889 & 1899 & 1904 & 1909 \\ \begin{array}{l}\text { Agriculture } \\ \begin{array}{l}\text { Resource-oriented } \\ \text { Manufacturing }\end{array}\end{array} & 9.8 & 18.3 & 13.2 & 13.2 & 11.0 & 10.5 \\ \begin{array}{l}\text { Other Manufacturing } \\ \text { Other }\end{array} & 8.2 & 12.1 & 9.8 & 11.3 & 9.4 & 7.3 \\ & 1.6 & 3.3 & 1.9 & 4.3 & 4.6 & 4.2\end{array}$

aFood products, Tobacco products, Petroleum and coal products, and Forest products.

Source: Unpublished compilations by Phyllis A. Wallace. See National Bureau of Economic Research, Thirty-third Annual Report, 1953 (New York, NBER, 1953). These ratios are lower than those of Table 12 because no deductions have been made here in the denominators for the purchase of inputs from other industries.

Thus, in both agriculture and resource-oriented manufacturing industries, for which export trade was relatively important - over ten per cent of production at times - the importance of export markets was declining. Resources were becoming less of a basis for American exports. In other manufacturing industries, on the other hand, for which the resource base was less important, 
exports rose as a per cent of production. That was particularly notable in metal products, machinery, and transport equipment (Table 14).

Table 14

Export/Output Ratios for Selected Manufacturing Industries, 1869 and 1909 (Per Cent)

$1869 \quad 1909$

Iron and steel products

Nonferrous metal products

1.7

1.7

3.2

Machinery

3.2
.8

9.3

7.7

Transportation equipment

3.2

Source: Same as Table 13

On the import side, the opposite changes were taking place. The shares of imports in domestic consumption were declining sharply for manufacturing as a whole and for almost every manufacturing group, the main exception being forest products (Table 15).

Table 15

Import/Consumption Ratios (Per Cent), 1869 and 1909

1869

1909

$\begin{array}{lrr}\text { Agriculture } & 5.8 & 8.3 \\ \text { Fishing } & 1.1 & 4.8 \\ \text { Mining } & 2.1 & 7.3 \\ & & \\ \text { Manufacturing } & 14.0 & 5.9 \\ \quad \text { Foods } & 19.8 & 9.5 \\ \text { Textile products } & 20.8 & 8.6 \\ \text { Chemical products } & 26.8 & 11.8 \\ \text { Forest products } & 3.6 & 3.6 \\ \text { Iron \& steel products } & 12.0 & 1.4 \\ \text { Nonferrous metal products } & 20.1 & 9.2\end{array}$

Source: Same as Table 13 
The import share of goods consumed generally increased for the resource industries, agriculture, fishing, and mining. In manufacturing, imports provided sharply decreasing shares of most products. Thus the Import data give clear indications of the shift in American comparative advantage toward manufacturing and away from natural resource products.

\section{The Commodity Composition of U.S. Trade in Relation to World Trade}

The changes in U.S. comparative advantage after the Civil War can be illustrated by the comparison of the composition of U.S. exports with that of world exports. The U.S. share of world exports of primary products fluctuated over a fairly narrow range from the 1870 s through the first years of the twentieth century and only fell somewhat in the decade or so before World War I (Table 16). The U.S. share of world manufactured exports remained at about 4 per cent through the 1880 s and then rose rapidly. Thus the shift in comparative advantage on the export side took place only at the end of the century despite the large shifts in U.S. production and employment mentioned above.

Another way of seeing this change is by comparing the composition of U.S. exports with that of world exports. The world ratio of manufactured product to primary product exports was quite stable at around sixty percent from the late 1870 s through 1913. The U.S. ratio was far lower, reflecting the U.S.comparative advantage as a primary product exporter, remaining at about sixteen to elghteen per cent from the 1870 s through the early 1890 s. Then, in the next twenty years, it rose to forty per cent, as the shift in production and employment from primary products to manufacturing finally began to be reflected in the composition of U.S. exports. 
Table 16

U.S. and World Exports of Primary Products and Manufactures

\begin{tabular}{|c|c|c|c|c|}
\hline & \multicolumn{2}{|c|}{$\begin{array}{c}\text { U.S. Exports as } \\
\text { Per Cent of World } \\
\text { Exports }\end{array}$} & \multicolumn{2}{|c|}{$\begin{array}{l}\text { Manufactures } \\
\text { Exports as Per Cent of } \\
\text { Primary Exports }\end{array}$} \\
\hline & $\begin{array}{l}\text { Primary } \\
\text { Products }\end{array}$ & Manufactures & World & U.S. \\
\hline $1871-75$ & NA & NA & NA & 16.8 \\
\hline $1876-80$ & 15.4 & 4.0 & 61.6 & 16.1 \\
\hline $1881-85$ & 16.0 & 4.2 & 62.5 & 16.2 \\
\hline $1886-90$ & 14.4 & 4.1 & 63.4 & 18.0 \\
\hline $1891-95$ & 16.1 & 4.7 & 58.5 & 17.0 \\
\hline $1896 \cdot 1900$ & 16.7 & 7.0 & 59.2 & 24.7 \\
\hline $1901-05$ & 16.0 & 8.0 & 57.7 & 28.9 \\
\hline $1906-10$ & 14.7 & 8.2 & 60.5 & 33.7 \\
\hline $1911-13$ & 13.8 & 9.2 & 60.7 & 40.5 \\
\hline
\end{tabular}

Source: League of Nations (1945), Tables VII, VIII, IX, and XIII. 
THE DIRECTION OF U.S. TRADE

\section{Changes in the Destination of Exports and the Origin of Imports}

American exports were directed mainly to Europe from the country's earliest days, and almost all that did not go to Europe were shipped to European colonies in the West Indies (Table 17). Since much of the trade pattern in these years reflected the effects of the Napoleonic Wars and the British blockade of Europe, some of the West Indies trade may have been disguised trade with Europe or a temporary substitute for European trade. The concentration of American exports on Europe increased over most of the 19th century, despite the growth of the industrial economy of the U.S. That growth was presumably giving the United States the capability of being more of a competitor to Europe in manufacturing, and less of a supplier of raw materials and foods, but the increasing focus on Europe as a market lasted through the $1880 \mathrm{~s}$, and was only sharply reversed after the $1890 \mathrm{~s}$. The same was true for the role of the U.K., which grew as a destination of U.S. exports from less than a quarter at the beginning of the $18 \mathrm{th}$ century, despite the ties of language and tradition, to over half in the 1870 s and 1880 s before falling back rather steeply after 1900. Some of the former UK share went to Germany in the late 19 th century and some of 1 went to the Western Hemisphere, as U.S. exports began shifting to less developed areas of the world.

Europe was about as important as a source of imports as it was as a destination for exports in the early decades of the 19th century (Table 18). However, for imports the trend in the European share was steadily downward, from two thirds or so to about half before World War $I$. The decline in the British share, and also in the French share, was steeper, while the German 
Table 17

Distribution of U.S. Exports (Including Re-Exports), by Destination $1790-1913$

\begin{tabular}{|c|c|c|c|c|c|c|}
\hline & \multirow[b]{2}{*}{ Total } & \multicolumn{3}{|c|}{ Europe } & \multicolumn{2}{|c|}{ America } \\
\hline & & Total & UK & Germany & Total & Canada \\
\hline & & \multicolumn{5}{|c|}{ Per Cent } \\
\hline $1790-98$ & 100 & 62 & 21 & 16 & $38^{\circ}$ & NA \\
\hline $1799-1808$ & 100 & 62 & 22 & 8 & $38^{\circ}$ & NA \\
\hline $1809-18$ & 100 & 69 & 28 & 3 & $31^{\circ}$ & NA \\
\hline $1819-28$ & 100 & 64 & 34 & 4 & $34^{b}$ & $3^{c}$ \\
\hline $1829-38$ & 100 & 71 & 43 & - & 27 & 3 \\
\hline $1839-48$ & 100 & 73 & 47 & - & 24 & 5 \\
\hline 1849.58 & 100 & 73 & 48 & - & 23 & 8 \\
\hline 1860 & 100 & 75 & 51 & 4 & 21 & 7 \\
\hline $1869-78$ & 100 & 81 & 54 & 9 & 17 & 6 \\
\hline $1879-88$ & 100 & 81 & 52 & 8 & 14 & 5 \\
\hline $1889-98$ & 100 & 79 & 48 & 11 & 16 & 6 \\
\hline $1899-1908$ & 100 & 72 & 36 & 14 & 19 & 8 \\
\hline $1904-1913$ & 100 & 66 & 30 & 14 & 25 & 12 \\
\hline
\end{tabular}

- less than 0.5 per cent.

-Total minus Europe

${ }^{\text {b}}$ Total minus Europe, 36 per cent, Asia, 2 per cent.

c1821-28

Source: U.S. Bureau of the Census (1975), Series U 317-334. According to Pitkin (1816), pp. 215-217, almost all the exports to "America" in 17951802 ( 36 per cent of the total, excluding exports to "Florida and Louisfana") were to the West Indies. 
Table 18

Distribution of U.S. General Iaporte, by Origin $1795-1913$

\begin{tabular}{|c|c|c|c|c|c|c|c|c|c|c|}
\hline & \multirow[b]{2}{*}{ Total } & \multicolumn{4}{|c|}{ Europe } & \multicolumn{4}{|c|}{ Americe } & \multirow{2}{*}{$\begin{array}{l}\text { Asla } \\
\text { Total }\end{array}$} \\
\hline & & Total & UK & France & Germany & Total & Caneda & Cuba & Brazil & \\
\hline $1795-1801$ & 100 & 52 & 35 & 2 & 5 & $38^{a}$ & 0 & $M$ & $\mathbf{M A}$ & 9 \\
\hline $\begin{array}{c}1821-28 \\
1829-38 \\
1839-48 \\
1849-58 \\
1860 \\
1869-78 \\
1879-88 \\
1889-98 \\
1899-1908 \\
1904-1913\end{array}$ & $\begin{array}{l}100 \\
100 \\
100 \\
100 \\
100 \\
100 \\
100 \\
100 \\
100 \\
100\end{array}$ & $\begin{array}{l}63 \\
64 \\
67 \\
66 \\
61 \\
54 \\
55 \\
52 \\
51 \\
50\end{array}$ & $\begin{array}{l}40 \\
37 \\
38 \\
42 \\
39 \\
33 \\
26 \\
21 \\
17 \\
17\end{array}$ & $\begin{array}{r}10 \\
15 \\
19 \\
14 \\
12 \\
9 \\
11 \\
9 \\
9 \\
8\end{array}$ & $\begin{array}{r}3 \\
3 \\
3 \\
5 \\
5 \\
7 \\
9 \\
12 \\
11 \\
11\end{array}$ & $\begin{array}{l}26 \\
22 \\
25 \\
26 \\
29 \\
35 \\
32 \\
33 \\
30 \\
32\end{array}$ & $\begin{array}{l}<1 \\
1 \\
1 \\
4 \\
7 \\
6 \\
6 \\
5 \\
5 \\
6\end{array}$ & $\begin{array}{r}9 \\
8 \\
8 \\
8 \\
9 \\
13 \\
9 \\
7 \\
6 \\
7\end{array}$ & $\begin{array}{r}2 \\
4 \\
5 \\
6 \\
6 \\
7 \\
7 \\
10 \\
7 \\
7\end{array}$ & $\begin{array}{r}11 \\
8 \\
8 \\
7 \\
8 \\
10 \\
11 \\
11 \\
16 \\
15\end{array}$ \\
\hline
\end{tabular}

of which 1 from "Florida and Loulsiane" and 37 froe the West Indies.

Source: U.S. Bureau of the Census (1975), Series U335-352 and Pitkin (1816), PP. 212-214. 
share of U.S. imports doubled. The other areas increasing in importance as sources of Imports were Canada and Asia.

The underlying causes of these shifts were changes in foreign supply and demand, arising from the growth of population and production in other countries, and changes in American supply and demand arising from U.S. growth and the changing structure of production.

The share of American exports going to Europe was not very different from the share of Europe's own exports other than to North America, going to Europe (intra-European trade) during much of the 19 th century, despite the extra cost of ocean transport for shipping goods from the U.S. (Table 19).

Table 19

Share of Europe as a Destination for Exports to or Origin of Imports From

\begin{tabular}{c} 
Europe \\
\hline Exports Imports \\
to from \\
(except to and from
\end{tabular}
North America)

1800

1830

1840

1850

1860

1870

1880

1890

1900

1910

$\begin{array}{ll}84 & \text { NA } \\ 82 & 70 \\ 76 & \text { NA } \\ 77 & 72 \\ 74 & 71 \\ 78 & 76 \\ 79 & 77 \\ 76 & 76 \\ 76 & 74 \\ 73 & 70\end{array}$

$\begin{array}{cc}\mathfrak{E}_{\text {to }} \text { U.S. } & \text { Imports } \\ & \text { from }\end{array}$

from

$\begin{array}{ll}58 & \text { NA } \\ 67 & 63 \\ 74 & 63 \\ 76 & 71 \\ 75 & 61 \\ 81 & 55 \\ 86 & 56 \\ 80 & 57 \\ 75 & 52 \\ 65 & 52\end{array}$

Source: Bairoch (1976a), Tables 21 and 22, and U.S.

Bureau of the Census (1975), Series U317, U324, U335 and U342

The similarity in export destinations, despite the differences in the stage of development between Europe and the U.S., suggests that these shares were determined mainly by the weight of Europe as a market. 
On the import side, the story was different; Europe remained the source of close to three quarters of Europe's imports other than those from North America throughout the century, but Europe declined as a source of U.S. imports after the mid-century. Elther the weight of Europe as a producer was falling or U.S. demand was shifting away from the mix of products sulted to Europe's comparative advantage as American manufacturing industries developed and their products supplanted imported manufactures in the U.S. market. The stability of Europe's share of U.S. exports, at least until the 1890 s or later, is linked to the stability of agriculture's share of U.S. exports, up to the 1880 s or 1990s. Both reflect the decline of European agriculture and the continued American comparative advantage in agricultural products. The decline in Europe's share of U.S. imports is linked with the falling share of finished manufactures in U.S. Imports, discussed earlier.

One way to judge the closeness of trade relations is to take account of the sizes of destination countries, by population, for example. Canada, which never accounted for a noticeable share of total U.S. exports, can be seen from the U.S. exports per capita to be much more closely tied to the U.S. by trade than many larger countries (Table 20). By this criterion of trade

Table 20

U.S. Exports Relative to Population in Importing Country (U.K. - 100)

$1870 \quad 1913$

$\begin{array}{lrc}\text { Canada } & 78 & 114 \\ \text { UK } & 100 & 100 \\ \text { Australia } & 36 & 80 \\ \text { Germany } & 20 & 58 \\ \text { France } & 14 & 25 \\ \text { Mexico } & 7.6 & 26 \\ \text { Brazil } & 7.2 & 13 \\ \text { Japan } & 0.4 & 8 \\ \text { China } & 0.1 & 0.4\end{array}$


"intensity", both income per capita in the importing country and a common language appears to be important positive influences, to judge by the high trade intensity with distant Australia and the intensity of trade with the UK relative to Germany and France.

On the import side, the intensity of trade, as measured now by U.S. imports per capita of origin country population, with U.K. - 100, was especially high with Canada, to a much greater degree than for export (Table 21).

Table 21

U.S. Imports Relative to Population in Exporting Countries

$\begin{array}{lrrr} & 1820 & 1870 & 1913 \\ \text { Canada } & \text { NA } & 186 & 230 \\ \text { UK } & 100 & 100 & 100 \\ \text { Australia } & \text { NA } & 24 & 51 \\ \text { Germany } & 5 & 21 & 67 \\ \text { France } & 11 & 22 & 47 \\ \text { Mexico } & \text { NA } & 6 & 75 \\ \text { Brazil } & \text { NA } & 49 & 73 \\ \text { Japan } & \text { NA } & 2 & 26 \\ \text { China } & 1 & 1 & 1\end{array}$

Mexico, Brazil, and Germany all exported more to the U.S. per person in the source country than did Australia, despite the common language. Propinquity, for Mexico and Canada, and the nature of each country's comparative advantage seemed to be more important in determining the sources of imports than were language or per capita income. 
TRENDS IN THE U.S. TERMS OF TRADE

\section{Aggregate National Terms of Trade}

The ratio of export to import prices, or terms of trade of a country (sometimes referred to as the "net barter terms of trade") measures changes in the purchasing power of exports: the quantity of imports purchased by each unit of export production. A rise in the terms of trade is often viewed as a favorable development for a country, and referred to as an "Improvement" In the terms of trade, although that interpretation is questionable at times. If a rise is the consequence of increasing demands for the country's export products, the effect on real income is favorable. However, if it is the consequence of a rise in costs relative to other countries, it is an unfavorable development, representing a decline in the country's ability to compete in international markets. That is true whether the rise in costs is the result of inflation or of productivity growth that is slower than in other countries.

It is widely believed that countries depending on primary products for export revenue tend to suffer declining terms of trade in the long run. Several reasons have been suggested as to why such a decline is to be expected. One is that price elasticities of demand for agricultural products are low. Increases in world production are not easily absorbed by gains in consumption and therefore result in relatively large price declines. Furthermore, income elasticities of demand for food are low; a rise in income leads to a less than proportional rise in food consumption. Food prices therefore are not lifted by increases in world income. In addition, it is said that agricultural products are sold in competitive markets and there is little opportunity for producers to exercise monopoly power to raise prices. 
In contrast, manufactured products are said to be subject to higher demand and income elasticities and to the raising of their prices through monopol1stic market practices.

Data on the terms of trade of the United States span a period of over 100 years, covering the metamorphosis from a primitive economy exporting almost entirely primary products to an industrial power with one of the world's highest income levels. On the whole, the picture is one of long-term improvement in the terms of trade - - perhaps an increase of two-thirds from the founding of the country to World War I (Table 22). The greatest gains took place before the Civil War, when the United States was almost entirely an

\section{Table 22}

Terms of Trade of the United States" (1913-100)

Period Terms of Trade Index

$\begin{array}{ll}1789-1798 & 58 \\ 1799-1808 & 66 \\ 1809-1818 & 60 \\ 1819-1828 & 65 \\ 1829-1838 & 79 \\ 1834-1843 & 83 \\ 1839-1848 & 77 \\ 1849-1858 & 90 \\ 1859-1868 & 80 \\ 1869-1878 & 87 \\ 1879-1888 & 97 \\ 1889-1898 & 90 \\ 1899-1908 & 97 \\ 1904-1913 & 99\end{array}$

"Export price index + import price index.

Source: Lipsey (1972). Table 14.3

exporter of primary -. largely agricultural -. products. These remained predominant through the end of the nineteenth century, as a gradual rise in the terms of trade continued. After the 1880 s, the terms of trade improved 
little, if at all. Within the nineteenth century history of the United States, therefore, there is no evidence that being an agricultural exporter led to an unfavorable evolution of the net barter terms of trade.

\section{Sectoral Price Trends}

Classical economic thought contained strong predictions about the longterm trends of the relative prices of agricultural and other primary products relative to manufactured goods. The classical view, starting at least as far back as Robert Torrens, continued by John Stuart Mill, and reinforced by Jevons' alarm at the exhaustion of British coal resources, was that "... the exchange value of manufactured articles, compared with the products of agriculture and of mines, have, as population and industry advance, a certain and decided tendency to fall." The opposite view was suggested from a reading of the factual record by Hilgerdt in a 1945 League of Nations report and was later promoted in a series of United Nations documents and articles, particularly by Raoul Prebisch and Hans Singer. That view was that primary goods prices had been declining secularly, and attributed the decline to low price and income elasticities for food, declining demand arising from the replacement of natural raw materials by synthetic materials, and monopolistic or oligopolistic pricing practices of manufacturing firms in developed countries that prevented buyers of manufactured exports from reaping the gains from productivity improvements in manufacturing.

The United States in the 19th century was a good laboratory in which to

JJohn Stuart Mill, Principles of Political Economy, New York, 1909, Vol. II, Book IV, Chapter 2, p. 282 
test these theories because the record of the aggregate terms of trade goes back to the period when agriculture was predominant and extends through the transformation to an industrial economy, and the record of agricultural and manufacturing prices and productivity also reaches to earlier stages of development than for most other countries.

Within U.S. exports, the price index for agricultural products, dominated by exports of cotton, was so volatile that it is hard to see a trend, but there were clearly large declines in prices of both agricultural and manufactured products between $1815-20$ and 1830 or the 1830 s as a whole. Since the export prices of manufactures did not fall as fast as agricultural export prices, the relative export prices of manufactures increased (Table 23). From the 1830 s to the 1850 s changes in relative prices were fairly small, not surprisingly in view of the fact that cotton and tobacco were very heavily weighted in the agricultural export price and cotton and tobacco manufactures accounted for 70 to 80 per cent of the weight in the manufactured goods price index. After 1879, there was a considerable decline in the price of manufactured exports relative to prices of agricultural exports, a movement that accorded with the classical expectations and contradicted the Prebischsinger view.

The basis for the classical belief that manufactured goods prices would fall in the long run was the conviction that productivity would grow more rapidly in manufacturing than in agriculture. That part of the prediction seems to have been correct, both before and after the Civil War. From 1879 to the beginning of World War I, manufacturing productivity rose more rapidly than agricultural productivity, and manufactured goods export prices fell relative to agricultural export prices (Table 23). The relative productivity 
Table 23

Relation Between U.S. Manufactured and Agricultural Product Export Prices and Total Factor Productivity

$1815-1860,1879-1913$

$\begin{aligned} \frac{\text { Export Price Indexes }}{\text { Manufacturing/Agriculture }} & \frac{\text { Productivity }}{\text { Agriculture/Manufacturing }} \\ (1859-60 & -100)\end{aligned}$

$1815-20$

$1821-30 \quad 113$

$1831-40 \quad 102$

$1839-40 \quad 100$

$1841-50$

$1849-50 \quad 98$

$1851-60 \quad 106$

$1859-60 \quad 100$

$1879-88$

$1889-98$

$1899-1908$

1904-13

\section{7}

\section{.}

128

130

119

109

100

$(1913-100)$

142

138

127

110
137

121

123

118

Sources: 1879-1913: Lipsey (1972), p. 575. 1815-1860: Price Indexes from North (1961); Real value added from Gallman (1960), p. 43; Labor force from Lebergott (1964), p. 510; Price Indexes are for individual years and decade averages; value added is for 1839,1849 , and 1859 and averages of 1839,1844 and 1849 and for 1849,1854 and 1859; labor force is for 1840,1850 , and 1860, and averages of first and last years of decade. 
change accounted for about sixty per cent of the relative export price change.

In the twenty years before the Civil War, a similar relative growth in manufacturing productivity did not have any counterpart in export price developments; the export price ratio for manufactured goods relative to agricultural products was quite stable. In the earlier period also, from 1815-20 to 1839-40 there was little change in the export price ratio. In this earlier period too, a comparison of Sokoloff's (1986) productivity measures for selected manufacturing industries with the Towne and Rasmussen (1960) productivity measures for agriculture suggests that manufacturing productivity was growing much faster than agricultural productivity.

There are several possible reasons why the productivity and price ratios do not match before 1860. After 1830, North's (1961 Appendix II, Table IV) export price index is dominated by cotton manufactures and to a much smaller extent, tobacco manufactures, both of which enfoyed productivity growth more rapid than that in agriculture (tobacco manufactures only after 1850 , according to Sokoloff). However, both industries' outputs included large elements of agricultural input and that may explain why North's manufactures price index rises by an amount identical to that of the raw material price index, dominated by cotton and tobacco.

Before 1830, the products in North's manufactures price index do not match Sokoloff's list well, the largest item in the price index being soap, not included by Sokoloff, and the second being tobacco manufactures, which not only include a large agricultural input content but also did not enjoy rapid productivity gains before 1850 .

The price and productivity movements of the post-Civil War period reveal the changes in the rewards to the factors of production in the two sectors. 
Just as the agricultural export price indicates the money return per unit of agricultural commodities sold, the ratio of the agricultural to the manufacturing price is one measure of the purchasing power of these agricultural commodities, assuming that manufactured exports are representative of U.S. manufacturing production in general. The product of the relative price and the agricultural productivity index indicates the course of returns to factors of production, or inputs, in agriculture: the purchasing power over manufactures of an hour of agricultural labor or a unit of capital employed in agriculture.

Agricultural factors of production did very well indeed after the 1890 s, by this measure (Table 24). Productivity in manufacturing increased much faster than in agriculture. Agricultural export prices rose rapidly, much faster than prices of manufactured goods. The purchasing power of agricultural factors over manufactured goods grew at a fast pace while the purchasing power of manufacturing factors of production over agricultural products actually fell. The gains from growing productivity in manufacturing went largely to agricultural factors of production and, of course to foreign purchasers of U.S. manufacturing exports.

\section{THE EFFECTS OF WARS AND OF TRADE POLICIES}

\section{The Navigation Acts}

Most of what we have described here as the development of American trade in the nineteenth century could be thought of as being outside the realms of both chance events or conscious policy. We have attributed trade developments mainly to income levels, productivity changes, factor endowments and changes in endowments. One possible exception to the unimportance of government 
Table 24

Agricultural and Manufactured Export Price Indexes and

Purchasing Power of Agricultural and Manufactured Products

\begin{tabular}{|c|c|c|c|c|}
\hline & \multicolumn{2}{|c|}{ Price Indexes } & \multirow{2}{*}{$\begin{array}{l}\text { Agricultural } \\
\text { Productivity } \\
\text { Index }\end{array}$} & \multirow{2}{*}{$\begin{array}{l}\text { Agricultural Factors' } \\
\text { Purchasing Power Over } \\
\text { Manufactured Exports }\end{array}$} \\
\hline & Agricul tural & $\frac{\text { Agricultural }}{\text { Manufactured }}$ & & \\
\hline $\begin{array}{c}1879-88 \\
1889-98 \\
1899-1908 \\
1904-1913 \\
1913\end{array}$ & $\begin{array}{r}83.6 \\
67.8 \\
77.0 \\
89.8 \\
100.0\end{array}$ & $\begin{array}{r}70.4 \\
72.4 \\
78.9 \\
90.6 \\
100.0\end{array}$ & $\begin{array}{r}93.7 \\
95.6 \\
106.6 \\
106.3 \\
100.0\end{array}$ & $\begin{array}{r}66.0 \\
69.2 \\
84.1 \\
96.3 \\
100.0\end{array}$ \\
\hline & Manufacturing & $\frac{\text { Manufactured }}{\text { Agricultural }}$ & $\begin{array}{l}\text { Manufacturing } \\
\text { Productivity } \\
\text { Index }\end{array}$ & $\begin{array}{l}\text { Manufacturing Factors' } \\
\text { Purchasing Power Over } \\
\text { Agricultural Exports }\end{array}$ \\
\hline $\begin{array}{c}1879-88 \\
1889-98 \\
1899-1908 \\
1904-1913 \\
1913\end{array}$ & $\begin{array}{r}118.5 \\
93.1 \\
97.0 \\
98.2 \\
100.0\end{array}$ & $\begin{array}{l}142.1 \\
138.2 \\
126.8 \\
110.4 \\
100.0\end{array}$ & $\begin{array}{r}69.1 \\
78.7 \\
86.8 \\
90.0 \\
100.0\end{array}$ & $\begin{array}{r}98.2 \\
108.8 \\
110.1 \\
99.4 \\
100.0\end{array}$ \\
\hline
\end{tabular}

Source: Lipsey (1963), Appendix Tables A-1 and A-3 
policies is the influence of the Navigation Acts on the trade pattern of the American colonies, the pattern with which the country began its existence.

The British government in the colonial period was no believer in leaving trade to the operation of the Invisible hand. As Adam Smith described the exemptions from the Navigation Laws, their purpose was to exploit the Incentives provided by access to foreign markets to encourage the cultivation of grain, the clearing and use of forests, and the raising of cattle beyond what would otherwise be feasible in "... a thinly populated country." The key to the success of the policy was the fact that access to "extensive markets" would cause the prices of these products to be high, as they would not be in a country cut off from trade. These high prices would encourage the extension of cultivation and improvement of the breed of cattle.

The other side of the Navigation Acts, and their main purpose, was to give home (British) purchasers of some colonial raw materials a monopoly on the output of the colonies, to keep prices low, and to severely restrict the growth in the colonies of manufacturing industries that might compete with British sellers.

The initial pattern of colonial trade fit well with these plans, since the exports were so largely crude materials and foods and imports were mainly manufactured products. However, the same pattern could be explained by the factor proportions and technological backwardness of the colonies. The fact that the evolution of the pattern of trade after Independence was gradual, and the fact that the United States moved toward greater concentration on trade with the U.K. after independence, when the earlier restrictions were absent, suggest that economic forces, rather than the Navigation Acts were the main determinants of both the commodity and country patterns of U.S. trade. 
A similar conclusion, minimizing the effects of British imperial policy on the welfare of the colonies and on the nature of their economies was arrived at by North (1974). He dismissed restrictions on manufacturing as inconsequential, given the colonies' factor proportions, which did not point to any comparative advantage in that fleld. That view was shared by many contemporary observers. For example, Benjamin Franklin (quoted in Callender 1909, pp. 35 and 36), "...while there is land enough in America for people, there can never be manufactures of any amount of value...the colonies are so little suited for establishing of manufacture, that they are continually losing the few branches they accidentally gain." There was a burden placed on American producers of tobacco, particularly, as measured by the difference between prices received and those available outside the U.K. And there were also burdens on consumers in the colonies from the artiflcially inflated prices of goods imported from other European countries. However, they were counterbalanced, to a considerable degree, by the advantages of British military protection (North, 1974, pp. 54-55).

North's analysis, treating 1785-1793 as the norm representing the situation without British restrictions, implies that if there were any effects from the restrictions they were short-lived and did not deflect the United States from its long-term growth path.

\section{The Napoleonic Wars and the Trade Embargo}

There is no doubt that the Napoleonic Wars and the accompanying trade embargo before the War of 1812 provided both great opportunities for trade and shipping, as is described in the earlier quotation from Callender, and also large negative shocks to the young U.S. economy. It is harder to say whether 
any of the effects were permanent, in the sense that the U.S. gained new industries that survived successfully after the period, or gained or lost footholds in world markets.

Most of the analyses of this period have focussed on the immediate advantages of American neutrality at a time when almost all potential rivals were swept from the trade scene. North describes the years 1793 through 1807 as "extraordinarily prosperous ones..." a characterization confirmed by "...numerous literary descriptions..." (p. 72). The prosperity came from shipping earnings (which on net balance grew from $\$ 5-8$ billion to $\$ 38-40$ billion), and from increases in export prices and terms of trade. Once the embargo on trade began in 1808 and especially with the entry of the U.S. into the war in 1812, these gains were reversed. Shipping earnings and exports fell drastically and the terms of trade turned against the United States. The embargo did have some effect in promoting manufacturing in the United States, but the path of development did not match American comparative advantage at the time, according to North, and the artificially induced industrialization quickly withered under postwar competition. Thus the net balance of the war period, despite the prosperity of its early stages, does not seem to have propelled American economic development in any substantial way.

A later review of even the prosperous part of the Napoleonic War period by Goldin and Lewis (1980) attempted to deflate the "legendary importance" of the neutrality period by estimating effects on the rate of growth of per capita income. The estimated gains, while perhaps not of legendary dimensions, were substantial -- increases in the annual growth rate of per capita income of something between 30 and 40 per cent. Although the authors 
refer to these income gains as not dramatic they do suggest that there were more permanent gains to development -. the growth of port cities and inland towns, additions to shipping tonnage, and the spread of banking and of commercialization in general.

\section{The Civil War}

The Civil War was the bloodiest of American history, was fought entirely on American Soll, and divided the country on economic lines to a large extent. Despite these factors, there has always been some belief that the northern states experienced economic gains from the war. However, North (1966, p. 149) judged that the war "...was not a major impetus to accelerated industrial growth..." and presumably was not a major setback either. The basis for the statement was that the acceleration of industrial growth and the development of manufacturing had taken place before the war. Gallman (1972) pointed to the heavy manpower losses during the war, the decrease in immigration, and the smallness of the industrial requirements of the military forces in that perlod. What the Civil War did do was to alter the relation between the northern and southern states, greatly reducing the per capita income level of the South, and widening the income differential between the South and other areas. There was also a major shift in the balance of political power that was relevant to trade policy, since the southern states, more dependent on exports and more oriented to free trade, lost to the northern states, which were more import dependent and more favorable to protectionist legislation.

The negative effects of the war on the United States as a whole are reflected in the earlier description of U.S. shares in world trade, which fell between 1860 and 1870 in an unusual interruption of the long-term upward 
trend. The net indebtedness of the U.S. tripled between the beginning of the war and the end.

The distribution of exports did not change in a way that would suggest that the war violently altered the American industrial structure. The share of finished manufactures grew, but not to a degree that suggested a major break in the upward trend. The share of cotton exports declined, but no faster than it did between the 1830 s and 1840s, and less than from the 1870 s to the 1880 s.

On the whole, the Civil War appears more as an interruption to the changes in the composition of production and exports that were taking place than as a spur to them.

\section{Effects of Tariff Policy}

The extent to which protectionist legislation promoted manufacturing industry by restricting foreign competition in the U.S. market has been a perennial subject for dispute. North (1966) mentions the possibility that the Tariff Acts of 1816, 1824, and 1828 helped revive some parts of the textile industry after the 1808 embargo and the War of 1812 severely damaged the industry, but suggests that by 1830 the industry, having become a net exporter, had no need for protection. He also suggested that the iron industry, so regulated by the British Navigation Laws, ${ }^{2}$ was protected by the high transport cost of its products.

The era after the Civil War is sometimes cited as a perlod in which the

2 While Great Britain encourages in America the manufacture of pig and bar iron, by exempting them from duties... she imposes an absolute prohibition upon the erection of steel furnaces and slit-mills in any of her American plantations." Smith (1776), Book 4, Chapter 7. 
United States used high tariffs successfully to encourage infant industries that eventually became giants. In 1869 , imports were 14 per cent of the consumption of manufactured goods, and by 1909 that ratio had fallen to 6 per cent. In every manufacturing industry in which the import share was 10 per cent or more in 1869, that share fell to half or less in 1909. The Iron and steel industry was an extreme case, with imports falling from 12 to about ly per cent. These declines suggest that some of the rapid growth in U.S. manufacturing involved import substitution: the replacement of imports by domestic production. That was obviously the case for shares of the market, but there were also a couple of examples of import substitution in the absolute sense, with declines in the amount of imports in an industry.

Two cases of import substitution in this absolute sense stand out in the nineteenth century, and both involve industries in which protection was increased. One was the large fall in imports of textiles before the Civil War. In this case the domestic industry had expanded under the embargo, which was, in effect, a prohibitive tariff, although it was never put in those terms. Taussig (1931) concluded that the embargo itself, rather than the tariffs adopted to preserve the industry, provided the main impetus to growth. Imports of iron and steel also fell between 1879 and 1899 , In a period when domestic consumption of these products more than doubled. Since the decline in imports was insignificant relative to the growth of production, it cannot have been the main impetus to such growth. Most appraisals of the history of the industry have concluded that, while protection and the decline of imports may have hastened the growth of some elements of the industry, particularly tin plate, they were not the major influence in the long run for the industry as a whole (Taussig, 1931; Temin, 1964). 
A study of the tariff on pig iron (Baack and Ray, 1974) concluded that the tariff on that product did raise the level of domestic production. Part of that effect was through the impact on the quality of imports. Since the tariff on pig iron was a specific duty, framed in terms of dollars per ton, it weighed much more heavily on cheap grades of pig iron than on expensive grades. The result was a decline in imports of low quality pig iron, and encouragement to domestic production at the low end of the quality scale.

In general, the historical studies of protection have attempted to learn whether protection was successful, in the sense of encouraging the production of the protected item. They do not, however answer the more important policy question as to whether the growth and welfare of the country was enhanced, rather than only that of the protected industries and the factors of production employed in them.

TRADE AND U.S. ECONOMIC GROWTH

The United States, through much of its history, has been pointed to as a country for which international trade was unimportant. At least it was a country that, until recently, considered international trade unimportant, gave little thought to it in policy making, and in which most branches of economics were taught as if the country were isolated from the rest of the world. One reason was the relatively low and, at times declining ratio of U.S. trade to U.S. output described earlier.

These low ratios have affected the recurrent debate about the importance of trade for U.S. economic growth, particularly growth in the 19 th century. A relatively modest role for international trade was assigned by Kravis (1972), partly on the argument that trade was too unimportant, in terms of its share 
of total output, to account for much of the growth in GNP or GNP per capita. A view of the economy as governed by some type of economy-wide production function in which inputs of factors of production lead to predictable outputs of product tends to find little room for any influence of trade. Output growth is assigned as far as possible to growth in the amounts of inputs or in their quality, to technological progress, and often to some unexplainable residual. What is missing from these analyses is the question of why the inputs of resources grew at the rate they $\mathrm{did}$, and the role played not only by the actual exports and imports, but also by the broader trading circumstances . - the existence of markets and the ability of producers and traders to have access to them.

The view that assigns a more crucial level to trade, and to the growth of foreign demand, has been associated with the work of Douglass North on U.S. economic growth. North described the role of growth in foreign demand for cotton in leading to the westward expansion of cotton farming and, in its wake, more general expansions in settlement and cultivation.

A review of these controversies by Jeffrey Williamson shifted the emphasis to a more general influence of trade: the existence of foreign demand, rather than its growth, and the likelihood, or almost certainty, that the price elasticity of demand in foreign markets was higher than that in the domestic market -. probably much higher. That high elasticity meant that rapid expansions of production, such as from the spread of cultivation to new areas, could take place without causing drastic reductions in the prices recelved by producers, Without the highly elastic demand of the foreign market, expansions of production would quickly face the effects of the low domestic demand elasticities, prices would fall quickly, and the expansion 
would be cut off. It is not implied that the elasticity of foreign demand for a product as a whole was necessarily different from that in the U.S. The higher foreign elasticity of demand for an American export arose from the fact that it was, typically, a much smaller element of foreign supply than of American supply. Therefore the American export could substitute for foreign exports or local production of the same product. If there were efficiencies to be gained from concentrating an expansion in production in a short period, they might well be lost if trade were cut off or reduced.

A corollary of this effect of the international market is that the ratio of exports to production should increase when production grows most rapidly. As described earlier, that was the case for cotton production in the United States, and it was also true of the surges in middle-western grain and meat production in the second half of the nineteenth century. Thus the existence of a high-elasticity market, in combination with the factors that initiated the surges in production, may have been crucial to the westward expansion of the country.

On a more speculative note, one might consider that the advice now being given to most developing countries urges policies that are outward- rather than inward-oriented, and favor neutrality or export promotion over import substitution. Since many currently developing countries are much smaller than the U.S. was during the early stages of its industrialization, the trade orientation may be more necessary than it was for a large, continental, developing country such as the U.S. already was during most of the century. On the other hand, an outward-oriented trade policy that encourages trade may have ramifications for many other aspects of government policy. It may affect investment, competition, monetary, and fiscal policies. It may affect the 
choice of industries by investors, and the productivity of domestic producers. These broader influences could go far beyond what is suggested by the amounts of goods actually traded. 


\section{References}

Baack, Bennett D., and Edward John Ray (1974), "Tariff Policy and Comparative Advantage in the Iron and Steel Industry: 1870-1929," Explerations in Economic History, Vol. 11, No. 1, January.

Bairoch, Paul (1973). "European Foreign Trade in the XIX Century: The Development of the Value and Volume of Exports (Preliminary Results)." The Journal of European Economic History, Vol. 2, No. 1. Spring, pp. 5-36. (1976a), Commerce Extérleur et Développement Économlque de l'Europe au XIX` Siècle, Paris, Mouton \& Co. and École des Hautes Études en Sciènces Sociales. (1976b), "Europe's Gross National Product: 1800-1975," Journal of European Economic History, Vol. 5, No. 2, Fall. (1982), "International Industrialization Levels from 1750 to 1980," Journal of European Economic History, Vol. 11, No. 2. Bairoch, Paul, and Bouda Etemad (1985), Structure Par Prodults des Exportations du Tiers-Monde, 1830-1937, Geneva, Librairie Droz. Berry, Thomas Senior (1978), Revised Annual Estimates of American Gross National Product: Preliminary Annual Estimates of Four Major Components of Demand, 1789-1889, Richmond, The Bostwick Press.

Bjork, Gordon C. (1963), "Stagnation and Growth in the American Economy, 1784-1792," University of Washington Ph.D. Dissertation, 1963. Ann Arbor, Michigan, University Microfilms. (1964), "The Weaning of the American Economy:

Independence, Market Changes, and Economic Development," Journal of Economic History, Vol. 24, December. 
Blomström, Magnus, Robert E. Lipsey, and Lennart Ohlsson (1988), Econemls

Relations Between the United States and Sweden. Stockholm, Svenska Handelsbanken and the Federation of Swedish Industries.

Bogart, Ernest Ludlow (1920), The Economic History of the United States,

Third Edition, New York, Longmans, Green and Co. , and Charles Manfred Thompson (1919), Readings in

the Economic History of the United States, New York, Longmans, Green and Co.

Callender, Guy Stevens (1909), Selections from the Economic History of the United States, 1765-1860, with introductory essays, Boston Ginn and Co. David, Paul (1967), "The Growth of Real Product in the United States before 1840: New Evidence, Controlled Conjectures," Journal of Economic History, 27, pp. 151-97.

Davis, Lance E. (1972), "Capltal and Growth," Chapter 8 in Davis, Easterlin, and Parker, Eds. (1972).

Davis, Lance E., Richard A. Easterlin, and William N. Parker, editors (1972). American Economic Growth: An Economists History of the Unfted States, New York, Harper \& Row, 1972.

Davis, Lance E., and Jonathan R.T. Hughes (1960). "A Dollar-Sterling Exchange, 1803-95," Economic History Review, Vol. XIII, No. 1, August, pp. 52-78. Reprinted in Purdue Faculty Papers in Economic History, 1956-1966, Homewood, Illinois, Richard D. Irwin, 1967. Deane, Phyllis, and A.W. Cole (1969), British Economic Growth. 1688-1959, Second Edition, University of Cambridge, Department of Applied Economics, Monographs, No. 8, Cambridge, Cambridge University Press. Edelstein, Michael (1982), Qverseas Investment in the Age of High Imperialism: 
The Untted Kingdom, 1850-1914, New York, Columbia University Press. Gallman, Robert E. (1960), "Commodity Output, 1839-1899," in NBER Conference on Research in Income and Wealth, Trends in the Amerlcan Economy in the Nineteenth Century, Studies in Income and Wealth, Vol. 24, Princeton, Princeton University Press for the NBER.

Gallman, Robert E. (1960), "Commodity Output, 1839-1899," in NBER Conference on Research in Income and Wealth, Irends in the American Economy in the Nineteenth Century, Studies in Income and Wealth, Vol. 24, Princeton University Press for the NBER. (1966), "Gross National Product in the United States: 1834 1909," in NBER Conference on Research in Income and Wealth, Qutput. Employment, and Productivity in the Unlted States After 1800, Studies in Income and Wealth, Vol. 30, New York, NBER.

(1972), "The Pace and Pattern of American Economic Growth," in Davis, Easterlin, and Parker (1972). (1992), "American Economic Growth before the Civil War: The Testimony of the Capital Stock Estimates," in Robert E. Gallman and John Joseph Wallis, Eds., American Economic Growth and Standards of Living Before The Civil War, Chicago, University of Chicago Press. Goldin, Claudia D., and Frank D. Lewis (1980), "The Role of Exports in American Economic Growth during the Napoleonic Wars, 1793 to 1807," Explorations in Economic History, Vol. 17, pp. 6-25.

Gordon, Robert J. (1989), "The Estimation of Prewar Gross National Product," Journal of Political Economy, February.

Kravis, Irving B. (1970), "Trade as a Handmaiden of Growth: Similarities Between the 19th and 20th Centuries," Economic Journal, Vol. 80, 
December, pp. 850-872. (1972), "The Role of Exports in Nineteenth-Century United States Growth," Economlc Development and Cultural Change, Vol. 20, Number 3, Apri1, pp. 387-405.

Kuznets, Simon (1961). Capltal in the American Economy: Its Formation and Financing, Princeton University Press for the NBER. (1966), Modern Economic Growth: Rate, Structure and Spread, Studies in Comparative Economics, No. 7, New Haven, Yale University Press.

League of Nations (1945), Industrlalization and Forelgn Trade, by Folke Hilgerdt, Geneva, League of Nations.

Lebergott, Stanley (1964), Manpower in Economlc Growth: The American Record Since 1800 , New York, McGraw-Hill Book Co. (1966), "Labor Force and Employment, 1800-1960," in NBER Conference on Research in Income and Wealth, Output, Employment, and Productivity in the United States After 1800 , Studies in Income and Wealth, Vol. 30, New York, NBER.

Lewis, Cleona (1938), America's stake in International Investments, Washington, D.C., The Brookings Institution.

Lipsey, Robert E. (1963), Price and Quantity Trends in the Forelgn Trade of the United States, Princeton, Princeton University Press for the National Bureau of Economic Research. (1972), "Foreign Trade," in Davis, Easterlin, and Parker (1972).

Maddison, Angus (1962), "Growth and Fluctuations in the World Economy, 1870- 
1960," Banca Nazionale del Lavoro Quarterly Review, No. 61, June, pp. 371. (1982), Phases of Capltalist Development, Oxford, Oxford University Press.

Mill, John Stuart (1909), Princlples of Political Economy, from the Fifth London Edition, New York, D. Appleton \& Co.

Mitchel1, B. R. (1978), European Historical Statistics, 1750-1970, Abridged Edition, New York, Columbia University Press.

Neal, Larry, and Paul Uselding (1972), "Immigration, A Neglected Source of American Economic Growth: 1790-1912," Oxford Economic Papers (New Series), Vol, 24, Number 1, March.

North, Douglass C. (1960), "The United States Balance of Payments, 1790-1860" in NBER Conference on Research in Income and Wealth. Trends in the American Economy in the Nineteenth Century, Studies in Income and Wealth, Vol. 24, Princeton, Princeton University Press for the NBER. (1961), The Economic Growth of the United States, 1790 to 1960, Englewood Cliffs, New Jersey, Prentice-Hall. (1966), Growth and Welfare in the American Past, Englewood Cliffs, New Jersey, Prentice-Hall. (1974), Growth and Welfare in the American Past, Second Edition, Englewood Cliffs, New Jersey, Prentice-Hall.

Pitkin, Timothy (1816), A Statistical Vlew of the Commerce of the United States. Reprints of Economic Classics, New York, Augustus M. Kelley, 1967.

Romer, Christina (1989), "The Prewar Business Cycle Reconsidered: New Estimates of Gross National Product, 1869-1908, " Journal of Political 
Economy, February.

Rostow, Walt W. (1978), The World Economy: History and Prospect, Austin, University of Texas Press.

Shepherd, James F., and Gary M. Walton (1972), Shipping, Maritime Trade, and the Economic Development of Colonial North American, Cambridge, Cambridge University Press.

Simon, Matthew (1960), "The United States Balance of Payments, 1861$1900, "$ in NBER Conference on Research in Income and Wealth, Trends in the American Economy in the Nineteenth Century, Studies in Income and Wealth, Vol. 24, Princeton, Princeton University Press for the NBER.

Smith, Adam (1776), An Inquiry Into the Nature and Causes of the Wealth of Nations, New York, Modern Library, 1937.

Smith, Walter Buckingham, and Arthur Harrison Cole (1935), Eluctuations In Amertcan Business, 1790-1860, Cambridge, Mass., Harvard University Press, 1935.

Sokoloff, Kenneth (1986), "Productivity Growth in Manufacturing During Early Industrialization: Evidence From the American Northeast: 1820-1860, " in Stanley L. Engerman and Robert E. Gallman, Editors, Long-Term Factors in American Economic Growth, Studies in Income and Wealth, Vol. 51, Chicago, University of Chicago Press for the NBER.

Taussig, Frank W. (1931), The Tariff History of the United States, New York and London, G.P. Putnam's Sons

Towne, Marvin W. and Wayne D. Rasmussen (1960), "Farm Gross Product and Gross Investment in the Nineteenth Century," in NBER Conference on Research in Income and Wealth, Trends in the American Economy in 
the Nineteenth Century, Studies in Income and Wealth, Vol. 24 , Princeton, Princeton University Press for the NBER.

U.S. Bureau of the Census (1975), Historlcal Statistics of the United States. Colonial Times to 1970. Bicentennlal Edition, Washington, D.C.

U.S. Congress, House of Representatives (1884), Domest1c Exports, 1789-1883.

House Miscellaneous Document No. 2236, 48th Congress, 1st Session (188384), compiled by C.H. Evans.

Vanek, Jaroslav (1963), The Natural Resource Content of Untted States Forefon Trade, 1870-1955, Cambridge, Mass., M.I.T. Press.

Weiss, Thomas (1992), "U.S. Labor Force Estimates and Economic Growth, 1800-1860," in Robert E. Gallman and John Joseph Wallis, Eds., American Economic Growth and Standards of Living Before the Civil War, Chicago, University of Chicago Press.

Weiss, Thomas (1993), "Estimates of Gross Domestic Output for the United States, 1800 to 1860," Mimeo, University of Kansas.

Wilkins, Mira (1989), The History of Foreign Investment in the United States to 1914, Cambridge, Mass., Harvard University Press.

Williamson, Jeffrey (1964), American Growth and the Balance of Payments, 18201913. Chapel Hill, University of North Carolina Press. 
</ref_section> 